\title{
MORPHOLOGICAL VARIABILITY OF THE LEAF EPIDERMIS IN SELECTED TAXA OF THE GENUS FICUS L. (MORACEAE) AND ITS TAXONOMIC IMPLICATIONS
}

\author{
MaŁgorZata KlimKo $^{1}$, Mariola TruchaN ${ }^{2}$ \\ ${ }^{1}$ Department of Botany, Agricultural University \\ Wojska Polskiego 71c, 60-625 Poznań, Poland \\ e-mail: klim@owl.au.poznan.pl \\ 2 Department of Botany and Genetics \\ Institute of Biology and Environmental Protection \\ Pomeranian Pedagogical University \\ Arciszewskiego 22b, 76-200 Słupsk, Poland
}

(Received: January 27, 2006. Accepted: April 22, 2006)

\begin{abstract}
The leaf epidermis of 36 taxa (species, subspecies, varieties and cultivars) of the genus Ficus (subgenera Ficus, Synoecia, Sycomorus, Pharmacosycea and Urostigma) was observed under LM and SEM. Characteristics of the epidermis are of particular taxonomic as well as phylogenetic interest because they differ conspicuously between species. The differences are especially prominent in the size and shape of epidermal cells, the shape of cell walls, peristomatal cuticular rim, the distribution and position of stomata, lithocysts, hydathodes, trichomes, and the types of wax, cuticle and trichomes. Results of this study provided data on new qualitative and quantitative traits of the leaf epidermis in the selected taxa, and confirmed the classification suggested by Berg (1989).
\end{abstract}

KEY WORDS: Ficus, Moraceae, leaf, epidermis, taxonomy.

\section{INTRODUCTION}

The first and very simple subdivision of Ficus was designed by Thunberg in 1786 and adopted by Vahl in 1805 (Berg 2003a). In 1844-1845 Gasparrini divided the genus Ficus L. into several genera. This concept was initially adopted by Miquel, who studied the genus Ficus worldwide (Berg 1989). Later on, Miquel (1847) decided to unite the previously distinguished genera into a single genus again, in which the former genera became elements of the primary subdivision of the genus. He provided a survey of approximately 550 species recognized at that time. Since then, many studies have contributed to the taxonomy of the genus Ficus and the number of species described has increased considerably. Nowadays the genus Ficus is made up of nearly 1000 species (Berg 1989) throughout tropical and warm temperate regions, with the greatest diversity in SE Asia, Malaysia, tropical South America, Africa and Australia. The genus includes a large number of indoor ornamental plants.

The genus shows considerable diversity in floral morphology and has been divided into subgenera, but the overall inflorescence morphology is so consistent and distinctive that these subgeneric segregates never came into general use. Corner (1960a, 1960b, 1965), divided the Asian and African members of the genus into four subgenera and a complex hierarchy of lower groups, based primarily on floral characters. Berg $(1989,2003 a)$ modified that subgeneric classification, giving more emphasis to vegetative characters and the traits related to reproduction and pollination systems. Berg's (2003a) division has been adopted in this study.

Despite a number of studies on Ficus leaf morphology (Corner 1960a, 1960b, 1965; Alexander 1989; Berg 2003a, b, c, 2004; Sonibare et al. 2004) and anatomy (Renner 1907; Metcalf and Chalk 1950; Philpott 1953; Lersten and Peterson 1974; Van Greuning et al. 1984; Mello Fhilo and Neves 1990), as well as cytomorphological (Hans 1972), molecular (Herre et al. 1996; Weiblen 2000; Datwyler and Weiblen 2004), chorologic (Corner 1960a, b; Berg 1998, 2003a, b, c) and taxonomic investigations (Ramirez 1977; Wiebes 1994, 1995; Berg 1998, 2003a, b, c, 2004; Dixon 2003), there are still many discrepancies in the delimitation of Ficus species and in the identification of vegetative specimens. It must be emphasized that ornamental taxa do not set seed in cultivation due to the lack of pollinators (Agaonidae, Blastophaginae).

Selected traits of the leaf epidermis in Ficus were studied by only few researchers, who used plants from their natural localities (Metcalf and Chalk 1950; Corner 1960- 
1965; Shah and Kachroo 1975; Mello Fhilo and Neves 1990; Sanibare et al. 2005; Chen and Chen 2005), but no reports have concerned Ficus cultivars.

The aims of this study were: (1) to analyse in detail the sculpture of the leaf epidermis of Ficus taxa; and (2) to identify the traits that are of diagnostic value for the differentiation of species and their cultivars in the vegetative stage.

\section{MATERIAL AND METHODS}

We studied 36 taxa of the genus Ficus 21 species, including 2 subspecies, 1 variety, and 16 cultivars) of 5 subgenera and 8 sections (Table 1). Live plant material specimens were obtained from the Botanical Garden, Adam Mickiewicz University, Poznań.

Leaf colour was determined on the basis of the RHS Colour Chart (2001).

The investigated microscopic qualitative features included: the cuticular and wax patterns, shape of cuticular thic-

TABLE 1. The classification of Ficus L.

\begin{tabular}{|c|c|c|}
\hline Subgenus & Section & Taxa \\
\hline Ficus L. & Ficus & $\begin{array}{l}\text { Ficus carica } \mathrm{L} . \\
\text { Ficus erecta Thunb. } \\
\text { Ficus erecta Thunb. var. sieboldii (Miq.) } \\
\text { Ficus neriifolia J. E. Sm. } \\
\text { Ficus pedunculosa Miq. }\end{array}$ \\
\hline Synoecia Miq. ex Mild \& Burret & Rhizocladus Endl. & $\begin{array}{l}\text { Ficus pumila } \text { L. 'Minima' } \\
\text { Ficus pumila } \text { L. 'Sonny' } \\
\text { Ficus sagittata } \text { Vahl }\end{array}$ \\
\hline Sycomorus (Gasp.) Miq. & Sycomorus & Ficus sycomorus L. \\
\hline Pharmacosycea (Miq.) Miq. & Pharmacosycea & Ficus pubinervis Blume \\
\hline \multirow[t]{4}{*}{ Urostigma (Gasp.) Miq. } & Galoglichia (Gasp.) Endl. & $\begin{array}{l}\text { Ficus barteri Spraque } \\
\text { Ficus cyathistipula subsp. cyathistipula Warb. } \\
\text { Ficus lyrata Warb. } \\
\text { Ficus natalensis subsp. leprieurii (Miq.) C.C. Berg }\end{array}$ \\
\hline & Urostigma & $\begin{array}{l}\text { Ficus benghalensis L. } \\
\text { Ficus benjamina } \text { L. ' } \\
\text { Ficus benjamina } \text { L. 'Exotica' } \\
\text { Ficus benjamina } \text { L. 'Foliole' } \\
\text { Ficus benjamina } \text { L. 'Golden King' } \\
\text { Ficus benjamina } \text { L. 'Monique' } \\
\text { Ficus benjamina } \text { L. 'Natasha' } \\
\text { Ficus benjamina } \text { L. 'Nina' } \\
\text { Ficus benjamina } \text { L. 'Starlight' } \\
\text { Ficus benjamina } \text { L. 'Variegata' } \\
\text { Ficus binnendijkii Miq. 'Alii' } \\
\text { Ficus microcarpa } \text { L. } \\
\text { Ficus religiosa } \text { L. }\end{array}$ \\
\hline & Malvanthera Corner & $\begin{array}{l}\text { Ficus macrophylla Pers. } \\
\text { Ficus rubiginosa Vent. }\end{array}$ \\
\hline & Stilpnophyllum Endl. & $\begin{array}{l}\text { Ficus elastica Roxb. } \\
\text { Ficus elastica } \text { Roxb 'Belize' } \\
\text { Ficus elastica } \text { Roxb 'Decora' } \\
\text { Ficus elastica } \text { Roxb 'Robusta' } \\
\text { Ficus elastica } \text { Roxb 'Schrijveriana' } \\
\text { Ficus elastica } \text { Roxb 'Variegata' }\end{array}$ \\
\hline Other & & Ficus triangularis Warb. \\
\hline
\end{tabular}

kenings of stomata, shape of epidermal cell walls, location and distribution of stomata, trichomes, lithocysts, wax glands, and hydathodes (Table 2).

Quantitative features investigated in this study included stomatal length (excluding the cuticular rim) and density on the abaxial surface (per $1 \mathrm{~mm}^{2}$ ).

Observations of leaf surface were conducted under scanning electron microscopes (Philips FEN 515 and ZEISS EVO 40) and a light microscope (Biolar, PZO, Poland).

The sculpture of the adaxial and abaxial epidermis of the leaves was studied on permanent slides (Klimko 1981) and on transverse sections of leaf blades. Stomatal density per $1 \mathrm{~mm}^{2}$ of the abaxial epidermis was calculated by using a calibrated reticulated eyepiece with the magnification of $\times 100$ (for stomatal length $\times 400$ ). Stomatal density and length were based on 30 measurements from each leaf. The number of analysed leaves ranged from 5 to 30, depending on leaf size.

Measurement results were characterized by using the arithmetic mean and standard deviation (Table 3). The inte- 
TABLE 2. A matrix of qualitative traits of leaves in Ficus sp. used in cluster analysis.

\begin{tabular}{|c|c|c|c|c|c|c|c|c|c|c|c|c|c|c|c|c|}
\hline Taxon / Features & 1 & 2 & 3 & 4 & 5 & 6 & 7 & 8 & 9 & 10 & 11 & 12 & 13 & 14 & 15 & 16 \\
\hline F. carica & 0 & 1 & 0 & 0.5 & 0 & 0 & 1 & 0 & 0 & 0 & 1 & 1 & 1 & 1 & 0 & 0 \\
\hline F. erecta & 0 & 0 & 0 & 0 & 0 & 0 & 1 & 0 & 0 & 0 & 1 & 1 & 0 & 1 & 1 & 1 \\
\hline F. erecta var. sieboldii & 0 & 0 & 0 & 0 & 0 & 0 & 1 & 0 & 0 & 0 & 1 & 1 & 0 & 1 & 1 & 1 \\
\hline F.neriifolia & 0 & 0 & 0 & 1 & 1 & 0 & 0 & 0 & 0.5 & 0.5 & 0 & 1 & 0 & 0 & 1 & 1 \\
\hline F. pedunculosa & 0 & 0 & 0 & 1 & 0 & 0 & 0 & 0 & 0 & 0 & 0 & 1 & 0 & 1 & 0 & 1 \\
\hline F. pumila 'Minima' & 0 & 0 & 0 & 1 & 0 & 0 & 1 & 0 & 0 & 0 & 1 & 0 & 0 & 1 & 1 & 1 \\
\hline F. pumila 'Sonny' & 1 & 0 & 0 & 1 & 0 & 0 & 1 & 0 & 0 & 0 & 1 & 0 & 0 & 1 & 1 & 1 \\
\hline F. sagittata & 0 & 0 & 1 & 1 & 0 & 0 & 1 & 0 & 0.5 & 0.5 & 1 & 0 & 0 & 1 & 0 & 1 \\
\hline F. sycomorus & 0 & 1 & 1 & 1 & 0 & 0 & 1 & 0 & 0 & 0 & 1 & 0 & 1 & 1 & 1 & 1 \\
\hline$F$. pubinervis & 0 & 0 & 1 & 0.5 & 0 & 1 & 0 & 0 & 1 & 1 & 0 & 0 & 1 & 1 & 0 & 1 \\
\hline F. barteri & 0 & 0 & 0 & 0 & 0 & 1 & 0 & 0 & 1 & 1 & 0 & 0 & 0 & 1 & 1 & 1 \\
\hline F. cyathistipula subsp. cyathistipula & 0 & 0 & 1 & 0 & 1 & 1 & 0 & 1 & 1 & 1 & 0 & 0 & 0 & 1 & 0 & 1 \\
\hline F. lyrata & 0 & 0 & 1 & 0.5 & 0 & 0 & 0 & 1 & 1 & 1 & 1 & 0 & 0 & 0 & 0 & 1 \\
\hline F. natalensis subsp. leprieurii & 0 & 0 & 0 & 0.5 & 0 & 0 & 0 & 0 & 0 & 1 & 1 & 0 & 0 & 0 & 1 & 1 \\
\hline F. benghalensis & 0 & 0 & 1 & 0 & 0 & 0 & 0 & 0 & 1 & 1 & 1 & 0 & 1 & 1 & 1 & 0 \\
\hline F. benjamina & 0 & 0 & 1 & 0 & 0 & 0.5 & 0 & 0 & 1 & 1 & 0 & 0 & 0 & 0 & 0 & 1 \\
\hline F. benjamina 'Exotica' & 0 & 0 & 1 & 0.5 & 0 & 0.5 & 0 & 0 & 1 & 1 & 0 & 0 & 0 & 0 & 0 & 1 \\
\hline F. benjamina 'Foliole' & 0 & 0 & 1 & 0.5 & 0 & 0.5 & 0 & 0 & 1 & 1 & 1 & 0 & 0 & 0 & 0 & 1 \\
\hline F. benjamina 'Golden King' & 1 & 0 & 1 & 0 & 0 & 0.5 & 0 & 0 & 1 & 1 & 0 & 0 & 1 & 0 & 0 & 1 \\
\hline F. benjamina 'Monique' & 0 & 0 & 1 & 0 & 0 & 0.5 & 0 & 0 & 1 & 1 & 0 & 0 & 0 & 1 & 0 & 1 \\
\hline F. benjamina 'Natasha' & 0 & 0 & 1 & 0.5 & 0 & 0.5 & 0 & 0 & 1 & 1 & 1 & 0 & 1 & 1 & 0 & 1 \\
\hline F. benjamina 'Nina' & 1 & 0 & 1 & 0.5 & 0 & 0.5 & 0 & 0 & 1 & 1 & 0 & 0 & 1 & 0 & 0 & 1 \\
\hline F. benjamina 'Starlight' & 1 & 0 & 1 & 0.5 & 0 & 0.5 & 0 & 0 & 1 & 1 & 0 & 0 & 0 & 0 & 0 & 1 \\
\hline F. benjamina 'Variegata' & 1 & 0 & 1 & 0.5 & 0 & 0.5 & 0 & 0 & 1 & 1 & 1 & 0 & 0 & 0 & 0 & 1 \\
\hline F. binnendijkii 'Alii' & 0 & 0 & 1 & 0.5 & 1 & 0.5 & 0 & 0 & 1 & 1 & 1 & 0 & 0 & 1 & 0 & 1 \\
\hline F. microcarpa & 0 & 0 & 1 & 0.5 & 1 & 1.5 & 0 & 0 & 1 & 1 & 0 & 0 & 0 & 0 & 0 & 1 \\
\hline F. religiosa & 0 & 0 & 0 & 1 & 1 & 0.5 & 0 & 0 & 0 & 0 & 1 & 0 & 0 & 1 & 1 & 1 \\
\hline F. macrophylla & 0 & 0 & 0 & 1 & 1 & 0 & 1 & 1 & 0.5 & 0.5 & 0 & 0 & 0 & 0 & 0 & 1 \\
\hline F. rubiginosa & 0 & 0 & 1 & 0.5 & 1 & 0 & 0 & 1 & 1 & 1 & 1 & 0 & 1 & 1 & 0 & 1 \\
\hline F. elastica & 0 & 0 & 1 & 0.5 & 0 & 1 & 0 & 0 & 1 & 1 & 0 & 0 & 0 & 0 & 0 & 1 \\
\hline F. elastica 'Belize' & 1 & 0 & 1 & 0.5 & 0 & 1 & 0 & 0 & 1 & 1 & 0 & 0 & 1 & 0 & 0 & 1 \\
\hline F. elastica 'Decora' & 0 & 0 & 1 & 0.5 & 0 & 1 & 0 & 0 & 1 & 1 & 0 & 0 & 0 & 0 & 0 & 1 \\
\hline F. elastica 'Robusta' & 0 & 0 & 1 & 0.5 & 0 & 1 & 0 & 0 & 1 & 1 & 0 & 0 & 0 & 0 & 0 & 1 \\
\hline F. elastica 'Schrijveriana' & 1 & 0 & 1 & 0.5 & 0 & 1 & 0 & 0 & 1 & 1 & 0 & 0 & 0 & 0 & 0 & 1 \\
\hline F. elastica'Variegata' & 1 & 0 & 1 & 0.5 & 0 & 1 & 0 & 0 & 1 & 1 & 0 & 0 & 0 & 0 & 0 & 1 \\
\hline F. triangularis & 0 & 0 & 0 & 1 & 1 & 1 & 1 & 0 & 0 & 0 & 1 & 0 & 0 & 0 & 0 & 1 \\
\hline
\end{tabular}

1. Leaves: completely green $=0$; variegated $=1$.

2. Leaf surface: smooth $=0 ;$ rough $=1$.

3. Epidermal cells polygonal: regularly $=0$; irregularly $=1$.

4. Cell walls in adaxial epidermis: straight $=0$; slightly undulated and straight $=0.5$; undulated $=1$.

5. Glandular wax: along veins and in angles between them $=0$; on leaf surface and edge $=1$.

6. Wax on abaxial leaf surface: granules $=0$; flakes $=0.5 ;$ mixed $=1$; rodlets $=1.5$.

7. Cuticle ornamentation: absent $=0$; present $=1$.

8. Distribution of stomata: everywhere between veins $=0$; in clumps $=1$.

9. Location of stomata: at the level of epidermis $=0$; slightly sunken $=0.5$; deeply sunken $=1$.

10. Cuticular thickening of stomata: absent $=0$; poorly developed 0.5 ; well developed $=1$.

11. Trichomes: absent $=0$; present $=1$.

12. Location of lithocysts with a cystolith: on both adaxial and abaxial leaf surface $=0$; on abaxial leaf surface $=1$.

13. Lithocysts in adaxial surface: absent $=0$; present $=1$.

14. Lithocysts in abaxial surface: absent $=0$; present $=1$.

15. Hydathodes in adaxial surface: absent $=0$; present $=1$.

16. Hydathodes in abaxial surface: absent $=0$; present $=1$.

ractions among quantitative features were tested using the Pearson's correlation coefficient. For the purpose of simple classification ANOVA was applied and the discriminating value of features was verified with the Tukey's post hoc test (Ott 1984; Łomnicki 2000). The shortest Euclidean di- stances were calculated in agglomerative grouping by the method of the closest neighbourhood for quantitative features (Karoński and Caliński 1973).

The Manhattan distances were calculated for binary coded date feature qualitative by Ward's method (Dobosz 2001). 
TABLE 3. Measurements of abaxial epidermal features expressed as mean and (SD).

\begin{tabular}{|c|c|c|}
\hline Taxon & $\begin{array}{l}\text { Length } \\
\text { of stomata } \\
\quad(\mu \mathrm{m})\end{array}$ & $\begin{array}{c}\text { Density } \\
\text { of stomata } \\
\text { per } 1 \mathrm{~mm}^{2}\end{array}$ \\
\hline F. carica & $33.35(2.84)$ & $68.90(6.24)$ \\
\hline F. erecta & $11.87(1.46)$ & $24.70(4.85)$ \\
\hline F. erecta var. sieboldii & $15.71(2.57)$ & $48.80(2.15)$ \\
\hline F. neriifolia & $26.40(2.13)$ & $90.00(4.55)$ \\
\hline F.pedunculosa & $22.97(3.08)$ & $80.00(5.72)$ \\
\hline F. pumila 'Minima' & $18.88(2.24)$ & $132.00(6.31)$ \\
\hline F. pumila 'Sonny' & $24.95(1.67)$ & $101.00(3.62)$ \\
\hline F. sagittata & $16.63(3.08)$ & $124.90(11.34)$ \\
\hline F. sycomorus. & $14.67(2.94)$ & $196.70(6.91)$ \\
\hline$F$.pubinervis & $30.62(2.87)$ & $42.10(2.85)$ \\
\hline F. barteri & $18.88(2.24)$ & $46.70(1.89)$ \\
\hline F. cyathistipula subsp. cyathistipula & $13.86(1.35)$ & $196.60(5.62)$ \\
\hline F. lyrata & $16.63(2.02)$ & $118.30(9.39)$ \\
\hline F. natalensis subsp. leprieurii & $14.00(1.40)$ & $37.90(15.42)$ \\
\hline F. benghalensis & $20.46(2.52)$ & $108.20(3.74)$ \\
\hline F. benjamina & $17.03(1.83)$ & $73.10(5.59)$ \\
\hline F. benjamina 'Exotica' & $31.40(3.88)$ & $45.40(4.25)$ \\
\hline F. benjamina 'Foliole' & $14.39(1.87)$ & $82.20(4.05)$ \\
\hline F. benjamina 'Golden King' & $18.08(5.31)$ & $79.60(5.76)$ \\
\hline F. benjamina 'Monique' & $17.16(1.91)$ & $46.10(6.47)$ \\
\hline F. benjamina 'Natasha' & $22.70(2.58)$ & $94.80(7.02)$ \\
\hline F. benjamina 'Nina' & $16.37(2.23)$ & $59.20(5.59)$ \\
\hline F. benjamina 'Starlight' & $13.09(2.20)$ & $54.30(3.53)$ \\
\hline F. benjamina 'Variegata' & $19.40(4.40)$ & $54.30(2.54)$ \\
\hline F. binnendijkii 'Alii' & $14.39(1.88)$ & $101.70(7.12)$ \\
\hline F. microcarpa & $20.46(3.16)$ & $52.33(1.94)$ \\
\hline F. religiosa & $21.91(2.31)$ & $54.64(3.41)$ \\
\hline F. macrophylla & $31.10(4.41)$ & $92.50(4.93)$ \\
\hline F. rubiginosa & $22.04(4.12)$ & $104.60(6.55)$ \\
\hline F. elastica & $26.77(1.42)$ & $38.90(2.02)$ \\
\hline F. elastica 'Belize' & $25.87(1.56)$ & $46.80(2.39)$ \\
\hline F. elastica 'Decora' & $24.16(3.40)$ & $31.30(2.83)$ \\
\hline F. elastica 'Robusta' & 30.77 (2.75) & $40.50(2.61)$ \\
\hline F. elastica 'Schrijveriana' & $23.10(2.86)$ & $40.10(3.07)$ \\
\hline F. elastica 'Variegata' & $20.33(2.46)$ & $41.10(2.69)$ \\
\hline F.triangularis & $14.56(1.62)$ & 41.40 (4.53) \\
\hline
\end{tabular}

The above mentioned methods are widely used in phenetic analysis (Sneath and Sokal 1973; Clifford and Stephenson 1975; McNeill 1975; Abbott et al. 1985; Stace 1993; Sokal and Rohlf 1997).

The Statistica 6 (StatSoft inc. 2002) software package was used to create dendrograms.

\section{RESULTS AND DISSCUSION}

Literature sources on the epidermal morphology of Ficus are rather scarce. The study of the epidermal leaf traits of Ficus revealed a number of important micromorphological characters and these characters exhibit interesting interspecific variations, which are of significance for identification.

In this study, we used plants growing under similar cultivation conditions, to minimize the modifying effect of environmental conditions on the variation in epidermal leaf traits.
All species have completely green leaf blades, but variegation was observed in some taxa, all of which being cultivars.

In some cultivars foliage is very colourful, with a moderately greyish-green centre and irregular golden, ivory or light greyish-green spots $(F$. benjamina L. 'Golden King', $F$. benjamina L. 'Nina', $F$. benjamina L. 'Starlight', $F$. benjamina L. 'Variegata' $F$. elastica Roxb. 'Belize', $F$. elastica Roxb. 'Variegata', F. elastica Roxb. 'Schrijweriana', $F$. pumila L. 'Sonny').

In Floras and keys to identification of species (Corner 1960-1965; Berg 1989-2004; Flora of China, Flora of North America), leaf surface is often taken into account.

Macroscopic observations show that the adaxial leaf surface is smooth and shiny in most of the studied taxa, but rough and matt in $F$. carica $\mathrm{L}$. and $F$. sycomorus $\mathrm{L}$., and undulated only in $F$. benjamina. The earlier describing of leaf surface as smooth is debatable in some species, e.g. in $F$. pumila, F . benghalensis L., F. barteri Spraque, F benjamina and $F$. elastica. The conducted LM and SEM observations show that on the adaxial surface of their leaves, there are unicellular trichomes (Figs 1,2) epidermal hydathodes (Fig. 3) lithocysts, silica-impregnated spines, (Fig. 5, arrow) and wax spots (Fig. 6, arrow) and cuticular thickenings of epidermal cells which seem to have a papillate sculpture in surface view (Figs 4, 5).

Epidermal cells on the adaxial and abaxial leaf surface vary considerably in size and shape, they are regularly or irregularly polygonal, with straight or undulated outer walls, and either straight or slightly undulated walls (Figs 6, arrow 7, 8). Within the subgenera Ficus and Urostigma, all three types of cell walls were observed, while within the subgenus Synoecia only undulated walls were found.

Only on veins epidermal cells of Ficus leaves are elongated, nearly rectangular. The shape of epidermal cell walls, as emphasized by Metcalf and Chalk (1950), Van Greuning et al. (1984), and Sonibare et al. (2005), can be considered as a good diagnostic feature for the identification of species on the basis of leaf anatomy.

Thus much variation is found in the glabrous and glabrescent species.

The most common are unicellular nonglandular trichomes, filiform with a bladderlike base between normal epidermal cells. Their base is often surrounded by a rosette of epidermal cells that form a characteristic rim (Fig. 9, arrows). Trichome shape and size are highly variable. Straight and long trichomes are predominant (Figs 9, 10, 14-16) and at times curved at the apex (Fig. 10) in F. carica. Peltate trichomes were observed on the abaxial surface in $F$. $c a$ rica (Fig. 9, arrow) F. sagittata Vahl, on the adaxial surface in $F$. binnendijki Miq 'Ali' and $F$. religiosa $\mathrm{L}$., and on both leaf surfaces in $F$. erecta Thunb, $F$. erecta Thunb.var. sieboldii (Miq.), F. pumila 'Minima' and 'Sonny', F. macrophylla Pers.

Trichomes of the second type are uniseriate, either filamentous in F. pumila "Sonny" (Fig. 11, arrows) and F. rubiginosa Vent., or capitate consisting of a usually one-celled stalk and a 1-5 celled head. The capitate trichomes are frequently called 'glandular'. The heads may be spherical in F. sagittata (Fig. 12) or elliptic in F. erecta (Fig. 13).

Various trichomes (straight and long, short and peltate) can be found on one leaf in some species, e.g. in F. carica (Figs 9, 10) and F. sycomorus (Fig. 16). The adaxial and abaxial surfaces do not differ in trichome types; when 

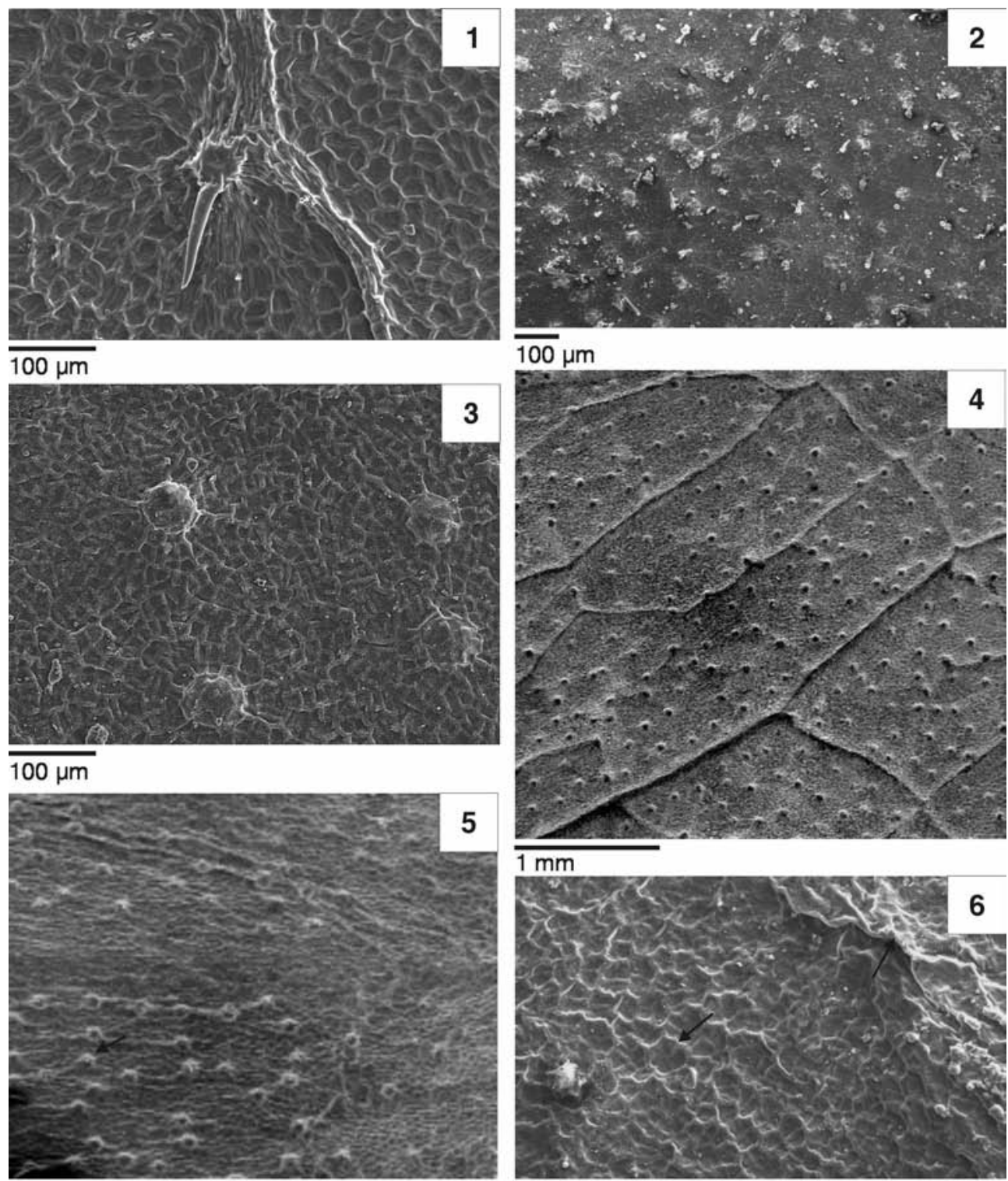

$\overline{100} \mu \mathrm{m}$
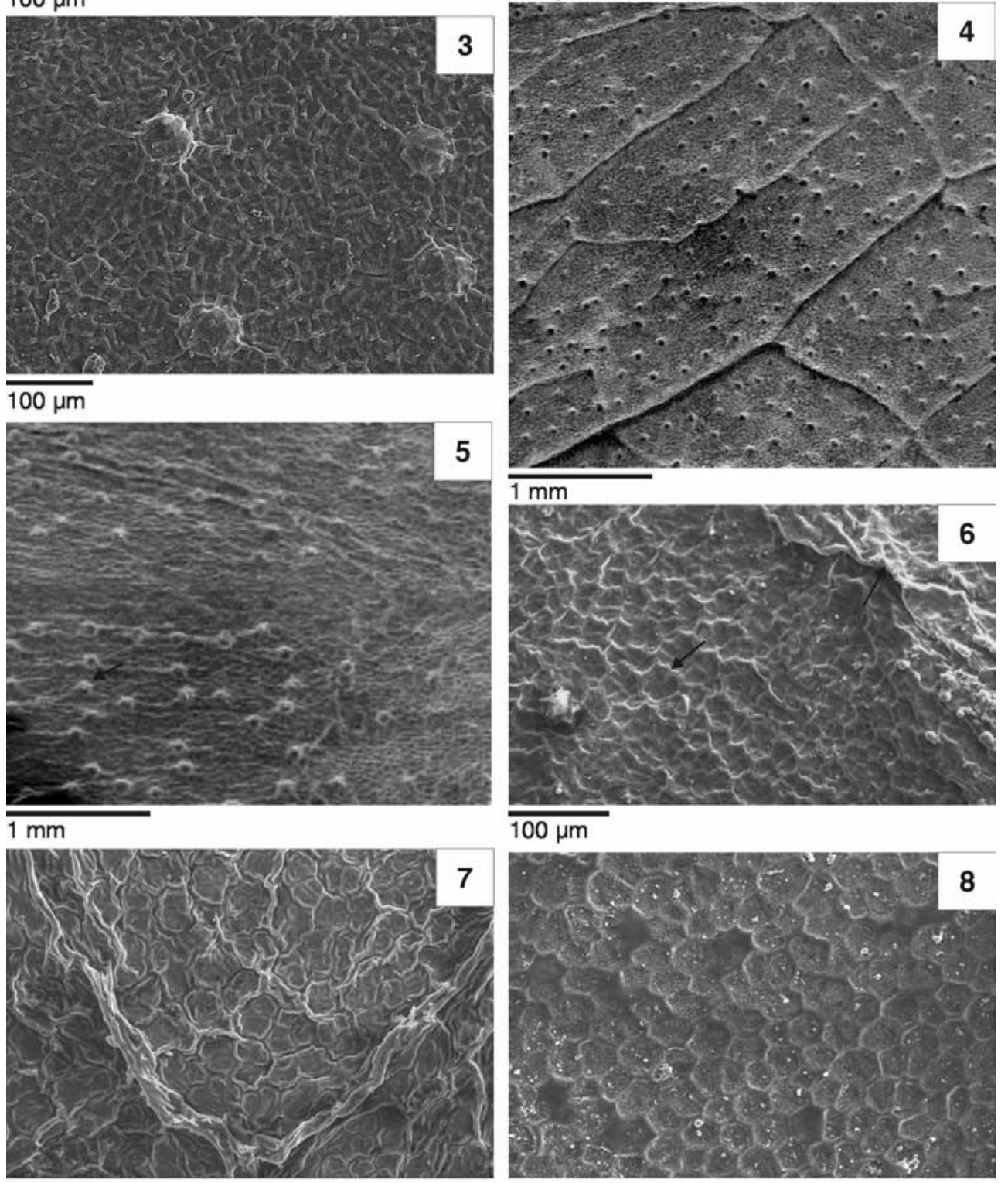

\section{$100 \mu \mathrm{m}$}

$100 \mu \mathrm{m}$

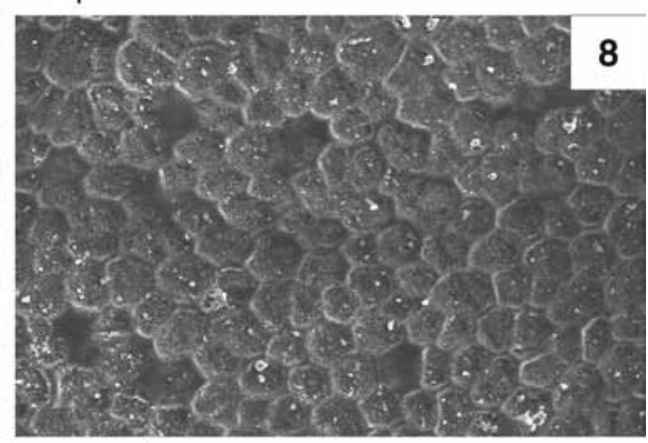

$100 \mu \mathrm{m}$

Figs 1-8. SEM. Adaxial epidermis of Ficus: Fig. 1. F. pumila 'Sonny'; Fig. 2. F. benghalensis; Fig. 3. F. barterii; Fig. 4. F. benjamina 'Foliole', note the papillar epidermis; Fig. 5. F. elastica 'Variegata', note the papillar epidermis; Fig. 6. F. macrophylla, note the wax glands; Fig. 7. F. pedunculosa, note the smooth epidermis; Fig. 8. F. religiosa, note the smooth epidermis. 

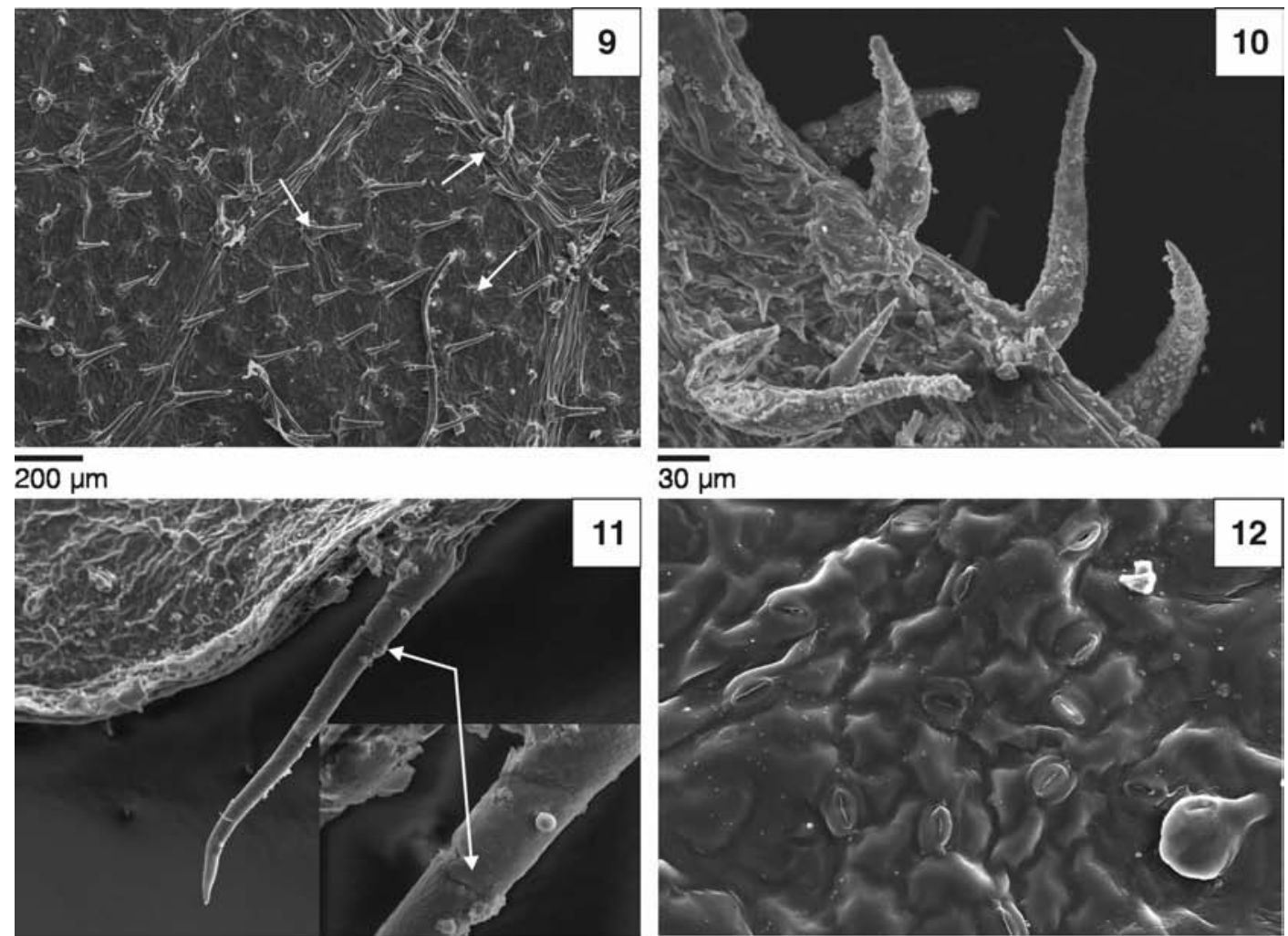

\section{$\overline{30 \mu \mathrm{m}}$}
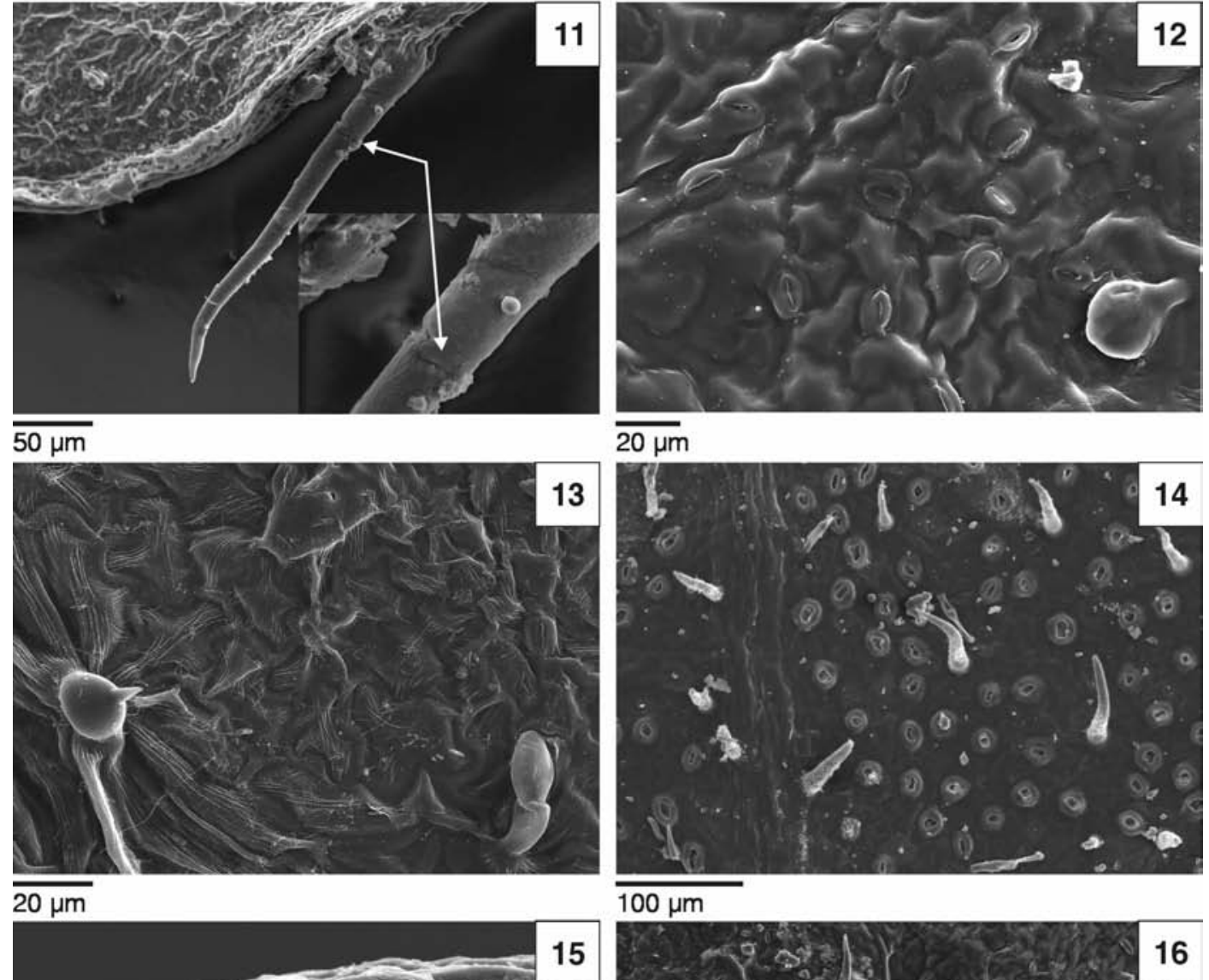

\section{$\overline{20 \mu \mathrm{m}}$}
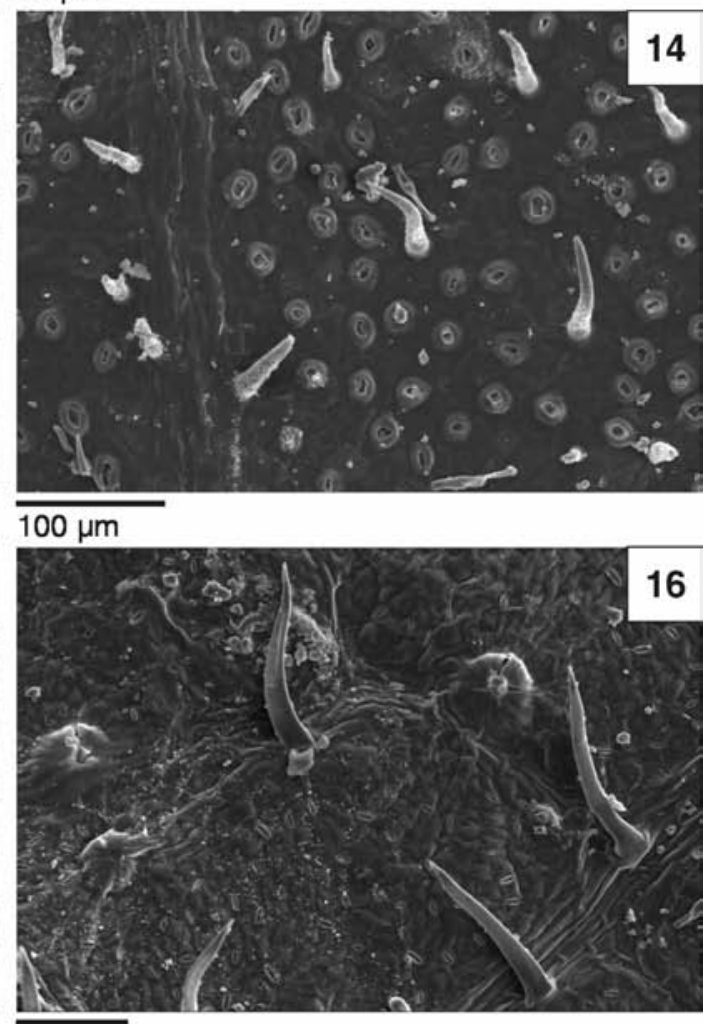

$\overline{20} \mu \mathrm{m}$

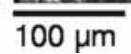

Figs 9-16. SEM. Abaxial epidermis of Ficus leaves with trichomes: Figs 9, 10. F. carica; Fig. 11. F. pumila 'Sonny', note the multicellular simple trichome; Fig. 12. F. sagittata, note the multicellular glandular trichome; Fig. 13. F. erecta var. sieboldii, note the multicellular glandular trichome and papillalike lithocysts; Fig. 14 F. benghalensis; Figs 15, 16. F. sycomorus. 
occurring in both the adaxial and abaxial epidermis, they are considerably denser and longer in the abaxial epidermis (Figs 2,14). On the leaf surface and veins, all trichomes are always scattered and never form clumps. On the leaf margin, trichomes are more or less crowded in some species, and longer e.g. in F. sycomorus than in other parts of the leaf blade (Figs 15, 16).

Based on the presence or absence of trichomes on the leaf epidermal surfaces, the taxa studied may be divided broadly into two groups, a glabrous group consisting of taxa without trichomes on either their adaxial or abaxial surfaces, and pubescent grouping comprising taxa with one or more trichome types on their leaf surface (Fig. 9).

The observed trichome types confirm the earlier reports on the family Moraceae (Metcalf and Chalk 1950; Shah and Kachroo 1975; Rohwer 1993) and some Ficus taxa (Sonibare et al. 2005), but also provide new data on the taxa that have not been described in this respect so far. Van Greuning et al. (1984) reported that in several species, glandular trichomes were seen on young, developing leaves, but they disappear as the leaves reach maturity. By contrast, in our study glandular trichomes were observed also on old leaves. However, this may be due to the fact that they were grown indoors.

In this study, the presence or absence of glandular trichomes on the epidermal surfaces of Ficus taxa was found to be less informative taxonomically. The nature of trichomes in the genus seems to be more reliable than their mere presence or absence (Sonibare et al. 2005). The taxonomic value of trichomes in this work was greatly limited by their absence in 18 of the 36 taxa of Ficus (Table 2).

Another important epidermal structure is the laminar hydathode. Little data have ever been published on the hydathodes of Ficus.

In the studied taxa, three types of laminar hydathodes were distinguished: forming pits (Fig. 17, arrow) or warts (Figs 18, 19, arrows) and stomata (Fig. 20, arrow). Hydathodes were present only on the adaxial leaf surface in 1 species, while on the abaxial leaf surface in 34 taxa and on both sides of the leaf blade in 9 taxa (Table 2). In many species some large stomata were present, elliptic in outline, occurring singly also on lateral veins, without cuticular thickenings at the level of epidermal cells. In this study, laminar hydathodes were not observed only in $F$. carica. Sonibare et al. (2005) reported that in 1884, De Barry noted water pores in adaxial epidermal depressions in at least 6 species of Ficus: F. neriifolia J. E. Sm., F. deltoidea Jack., $F$. callosa Willd., F. granatum Forst., $F$. saussureana DC and F. septica Burm. Molisch (1916) described the anatomy of the hydathodes in $F$. javanica Reinw. on the upper surface of the leaf, whereas Lersten and Peterson (1974) later illustrated the structure of hydathodes in $F$. deltoidea. Sonibare et al. (2005) described hydathodes in 4 species: $F$. sur Forsk., F. vallis - choudae Del., F. lutea Vahl and F. sansibarica subsp. macrosperma (Mildbr, \& Burret) C.C. Berg. Recently, Chen and Chen (2005) analysed the morphology and ultrastructure of laminar hydathodes in F. formosana Maxim f. shimadai Hayata. In our study, laminar hydathodes were found in 35 Ficus taxa (Table 2). In relation to the total number of Ficus species, the available information is still scant.

A characteristic feature of leaves of the family Moraceae, including Ficus species and their cultivars, is the fact that they contain idioblasts with crystals of calcium carbonate, calcium oxalate or silica. The crystals occur not only in special lithocysts, but are also widespread in normal cells of the epidermis or in trichomes (Esau 1965).

The location of lithocysts on the adaxial and/or abaxial epidermis (Table 2) and their various types [(lithocyst spine, lithocyst trichome (Fig. 10), papilla-like lithocyst (Fig. 13), or lithocyst with a cystolith)] can be regarded as good taxonomic features for distinguishing between species or even taxa of lower rank (Corner 1965; Berg 2003a, b, c, 2004). For example, within the subgenus Sycomorus the lithocysts with a cystolith occurred on both surfaces in $F$. sycomorus, but only on the abaxial leaf surface in $F$. sur (Van Greuning et al. 1984). Similarly, in the subgenus Urostig$m a$, cystolith were observed on both leaf surfaces, but in other species, e.g. F. verruculosa Warb., F. ingens (Miq.). Miq., F. salicifolia Vahl, and F. cordata Thunb., cystolith were located only abaxially (Van Greuning et al. 1984).

The distribution of cystolith - lithocysts varied considerably between species and within subgenera. In the subgenus Ficus, lithocysts with a cystolith were observed on the abaxial leaf surface. In the other subgenera and all sections they were found in both abaxial and adaxial epidermis (Table 2). The type of lithocysts is not related to the number of layers of the leaf epidermis.

The cuticle was covered with epicuticular wax. Metcalf and Chalk (1950), Rohwer (1993), and Berg (2003a, b, c, 2004) reported that in many Ficus species waxy glandular spots are found, mainly on the abaxial leaf surface. They were distributed always singly at the bases of the midrib on the abaxial leaf surface and at the bases of primary lateral veins, or also in angles between veins.

In this study, they were found not only near veins on the abaxial leaf surface, but also on both leaf surfaces (adaxial and abaxial) and on the leaf margin (Figs 21-26, arrows). Their aggregations were sometimes markedly elevated above the leaf surface and their shape was irregular. According to Rohwer (1993), the function of these glandular spots is unknown. Detailed SEM observations of the abaxial leaf surface showed that the wax layer is usually granulate (in 15 taxa), but it forms flakes in F. natalensis subsp. leprieurii (Miq.) C.C. Berg (Fig. 32), F. religiosa (Fig. 33), $F$. benjamina and its cultivars (Figs 35-38), F. binnendijkii 'Alii' and rodlets in F. microcarpa (Fig. 46), both rodlets and flakes in F. triangularis Warb. (Fig. 34), F. pubinervis Blume, F. cyathistipula subsp. cyathistipula Warb. (Fig. 49) and both granules and flakes in F. barteri, F. elastica; or both granules and threads in F. elastica 'Robusta'. Detailed observations of epicuticular wax on the abaxial surface provided new data.

So far, only wax from the adaxial epidermis has been described in 29 species of the genus Ficus, where it formed a crust, film flakes, a fissured layer, platelets and rosettes of platelets, granules, or was lumpy (Sonibare et al. 2005). Recrystallization experiments showed that the wax structure depends mainly on environmental conditions. A negative influence of environmental factors may be reflected in a modification of wax structure (Hejnowicz 2002).

Details of the structure of the outer cuticle, particularly its sculpture, attest to the variation between species. On the abaxial epidermis, the cuticle can be striate (Figs 27-30), smooth (Fig. 31), micropapillate (Figs 38, 40-42) or mixed [i.e. composed of several types of structures, more or less 

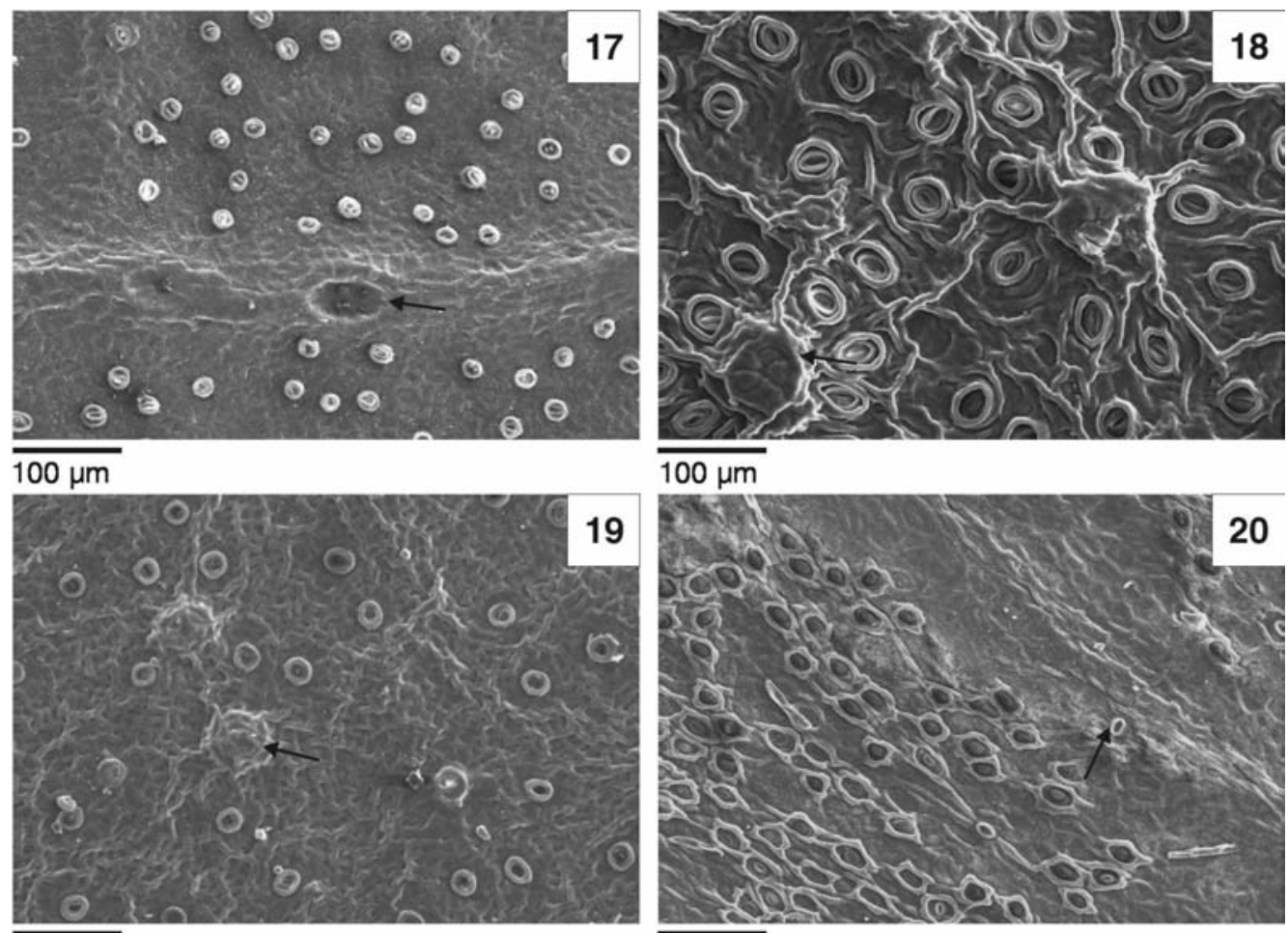

\section{$100 \mu \mathrm{m}$}

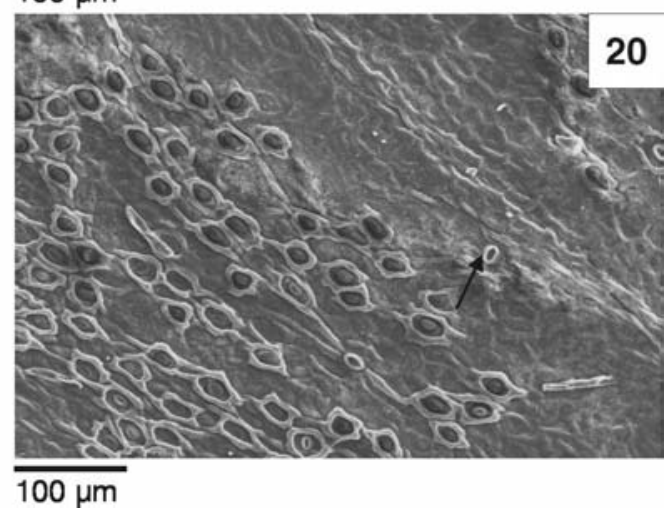

Figs 17-20. SEM. Abaxial epidermis of Ficus leaves with hydathodes: Fig. 17. F. benjamina; Fig. 18. F. elastica 'Belize'; Fig. 19. F. barterii; Fig. 20. F. lyrata.

homogeneous (Figs 34, 46, 47, 49)]. The striate cuticle forms a characteristic ornamentation and is a constant feature in 8 species (Table 2). The striations are irregular in ornamentation and height or occasionally radiating from the guard cells. Such a cuticle type is found in most of the studied species of the subgenera Ficus, Synoecia and Sycomorus. Within the subgenus Urostigma, ornamentation was observed in F. macrophylla around stomata (Fig. 30). Only in F. benjamina 'Variegata' (Fig. 38), F. elastica and its cultivars the convex cuticle is deposited sinuously along the cell walls, which contrasts with all the other studied taxa (Figs 39-42).

The leaf cuticle is one of the most characteristic features of epidermal phenotype, and cuticle type is a good diagnostic feature for distinguishing between species, subspecies, and taxa of lower rank.

In this study, we did not confirm the presence of a banded cuticle in $F$. natalensis subsp. leprieurii on the adaxial and abaxial epidermis, and a smooth cuticle in F. lyrata, $F$. barteri on the abaxial epidermis, which was reported by Sonibare et al. (2005).

Ficus leaves are hypostomatic (Metcalf and Chalk 1950; Rohwer 1993; Van Greuing et al. 1984; Sonibare et al. 2005). This was confirmed in our study. We found that stomata in the studied species are anemocytic. The outlines of the pair of guard cells are usually suborbiculate to wide elliptical, as seen in the surface view.

By contrast, Sonibare et al. (2005) reported that stomata in Ficus are mostly paracytic. In most of the studied taxa, stomata were distributed throughout the leaf surface between veins (Figs 14, 16-19). Moreover, in some species sto- mata formed characteristic aggregations: in several large groups (Figs 43-45) between veins ( $F$. cyathistipula subsp. cyathistipula, F. lyrata Warb., F. rubiginosa), or in small groups of 5-7 stomata each (Fig. 30). Stomata were located at the level of the others epidermis cells, but could also be sunken either slightly in mesomorphic species or deeply sunken in xeromorphic forms. In most species of the subgenus Urostigma, stomata were surrounded with a cuticular thickening, which formed a characteristic rim (Figs 14, 17$19,35-42,46$ ) or were polygonal in outline (Figs 47, 48) or interrupted (Fig. 49).The epidermal walls of the outer stomatal ledge are distinctly higher than the peristomal only in F. lyrata (Fig. 47) and F. rubiginosa (Fig. 48). The rim does not vary within taxa. The presence of the cuticular rim in about $64 \%$ of the taxa studied is of special importance. Mean stomatal length varied from 11.87 to 33.35 um (Table 3). Mean length of less than $15 \mu \mathrm{m}$ was recorded in eight taxa. In a majority of taxa, mean stomatal length fell within the range of 15 to $30 \mu \mathrm{m}$ (Table 3). Van Greuning et al. (1984) for Ficus taxa from Southern Africa reported a range from 16.00 to $30.0 \mu \mathrm{m}$. Sonibare et al. (2005) found that it varied from 7.80 to $25.40 \mu \mathrm{m}$. Results of the present study (Table 3) differ considerably only from the values recorded by Sonibare et al. (2005), e.g. for $F$. barteri $(16.20 \mu \mathrm{m}), F$. cyathistipula subsp. cyathistipula $(8.90$ $\mu \mathrm{m}), F$. lyrata $(8.50 \mu \mathrm{m})$, and $F$. natalensis subsp. leprieurii $(25.40 \mu \mathrm{m})$. Mean stomatal density (i.e. the number of stomata per $1 \mathrm{~mm}^{2}$ ) on the abaxial surface ranged from 24.70 to 196.70 (Table 3 ). The mean values exceeding 100 were found in nine taxa. Cultivars of $F$. benjamina varied widely in stomatal length and in stomatal density (Table 3). Large 

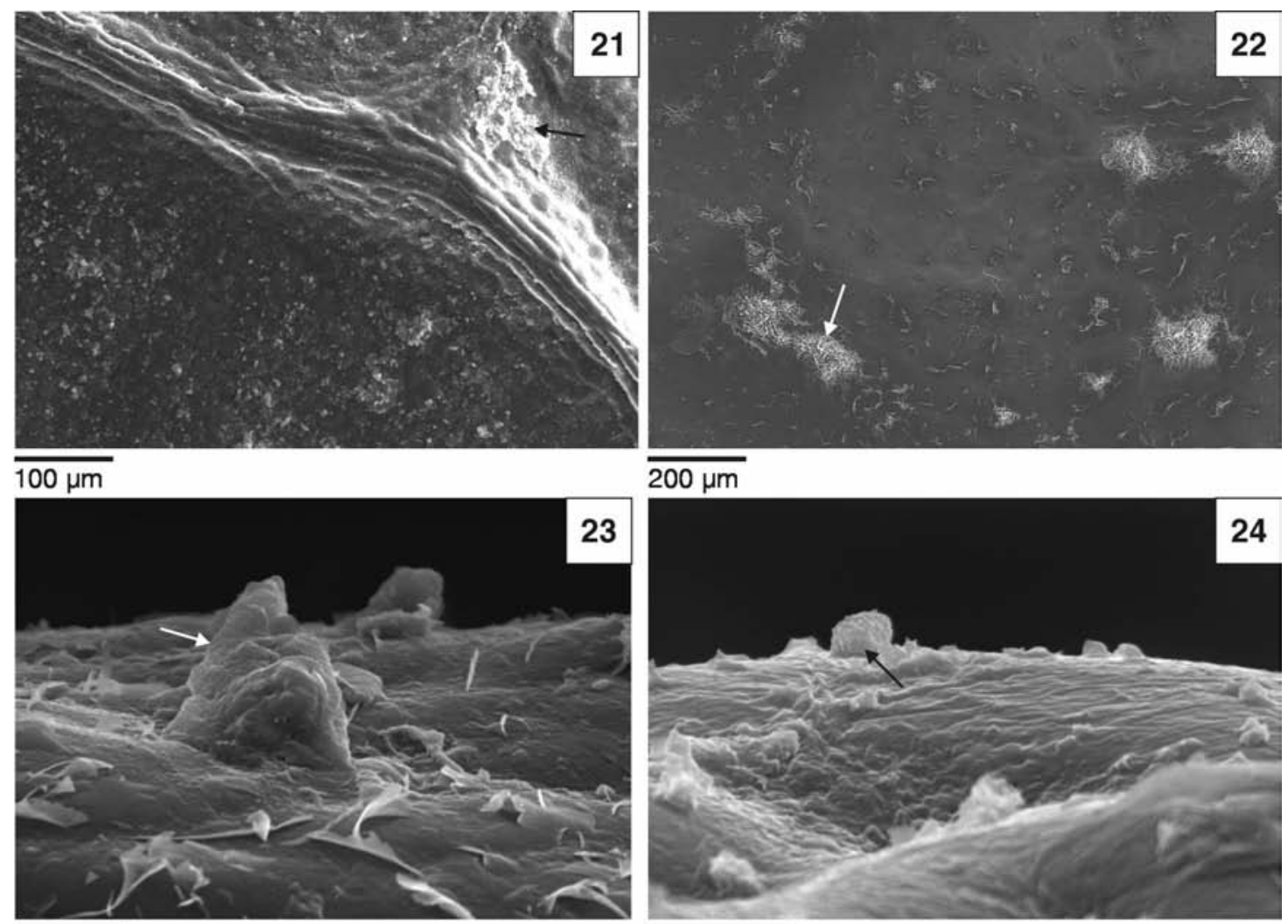

\section{$\overline{200 \mu \mathrm{m}}$}
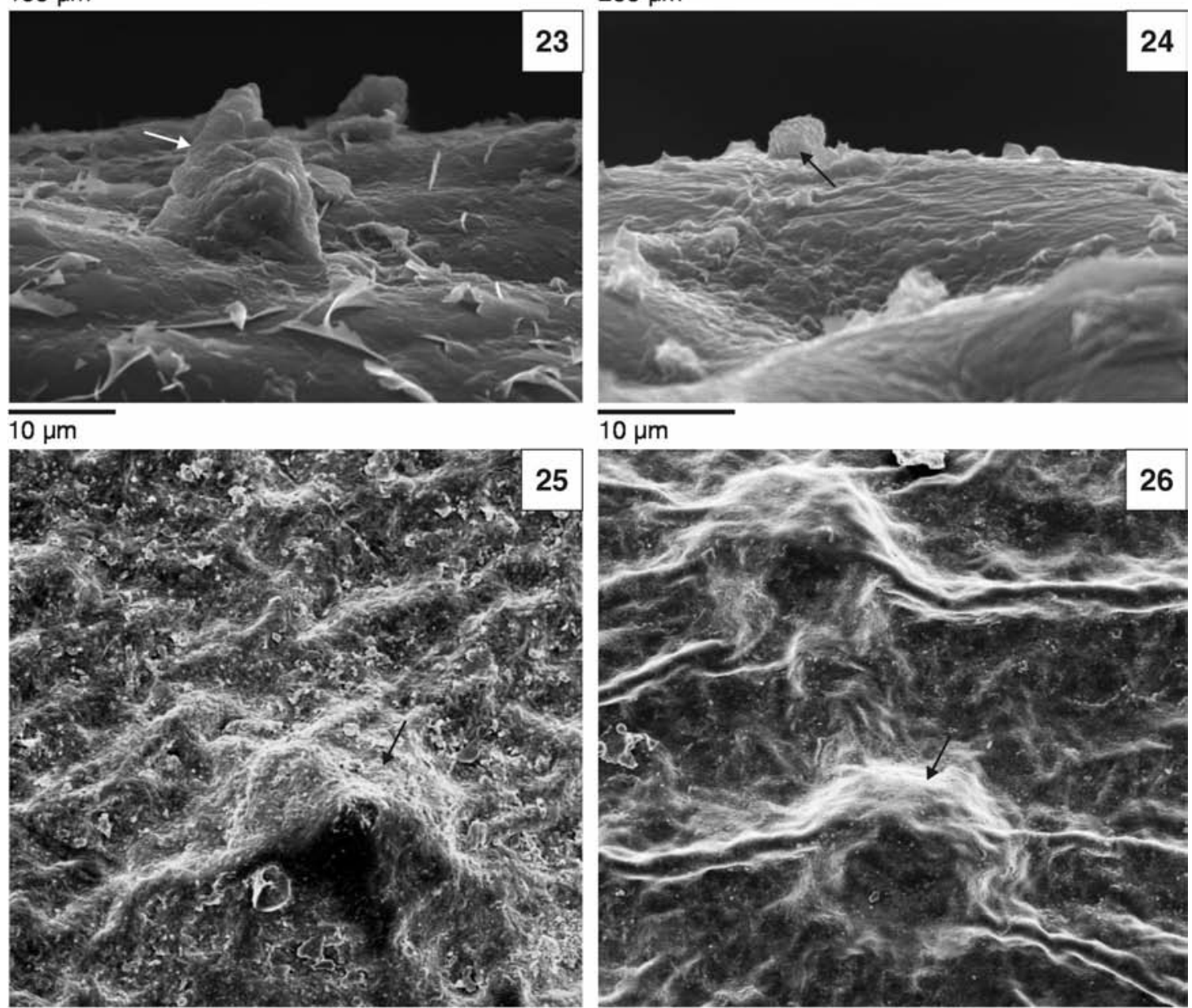

$30 \mu \mathrm{m}$

$100 \mu \mathrm{m}$

Figs 21-26. SEM. Adaxial epidermis of Ficus leaves with wax glands: Fig. 21. F. neriifolia, note the wax glands in angles between veins; Figs 22, 23. F. pubinervis, note the wax glands on leaf blade surface and margin, respectively; Fig. 24. F. pedunculosa, note the wax glands on leaf blade surface and margin, respectively; Fig. 25. F. benjamina 'Foliole', note the wax glands on the midrib; Fig. 26. F. elastica 'Variegata', note the wax glands on the midrib.

differences in stomatal length and density were also found between two cultivars of $F$. pumila. The variegate, small leaves of $F$. pumila 'Sonny' were characterized by longer but less numerous stomata than the green leaves of $F$. pumila 'Minima' (Table 3). F. erecta and F. erecta var. sieboldii also varied in both stomatal length and density.
The size of stomata and the number of chloroplasts is considered to be an indirect method in studies on polyploidy (Winkelmann and Grunwaldt 1995). Natural hybridization and poliploidy in the family Moraceae and genus $\mathrm{Fi}$ cus are extremely rare (Stebbins 1958; Bolkhovskikh et al. 1969). Cytology was examined in 146 species and most are 

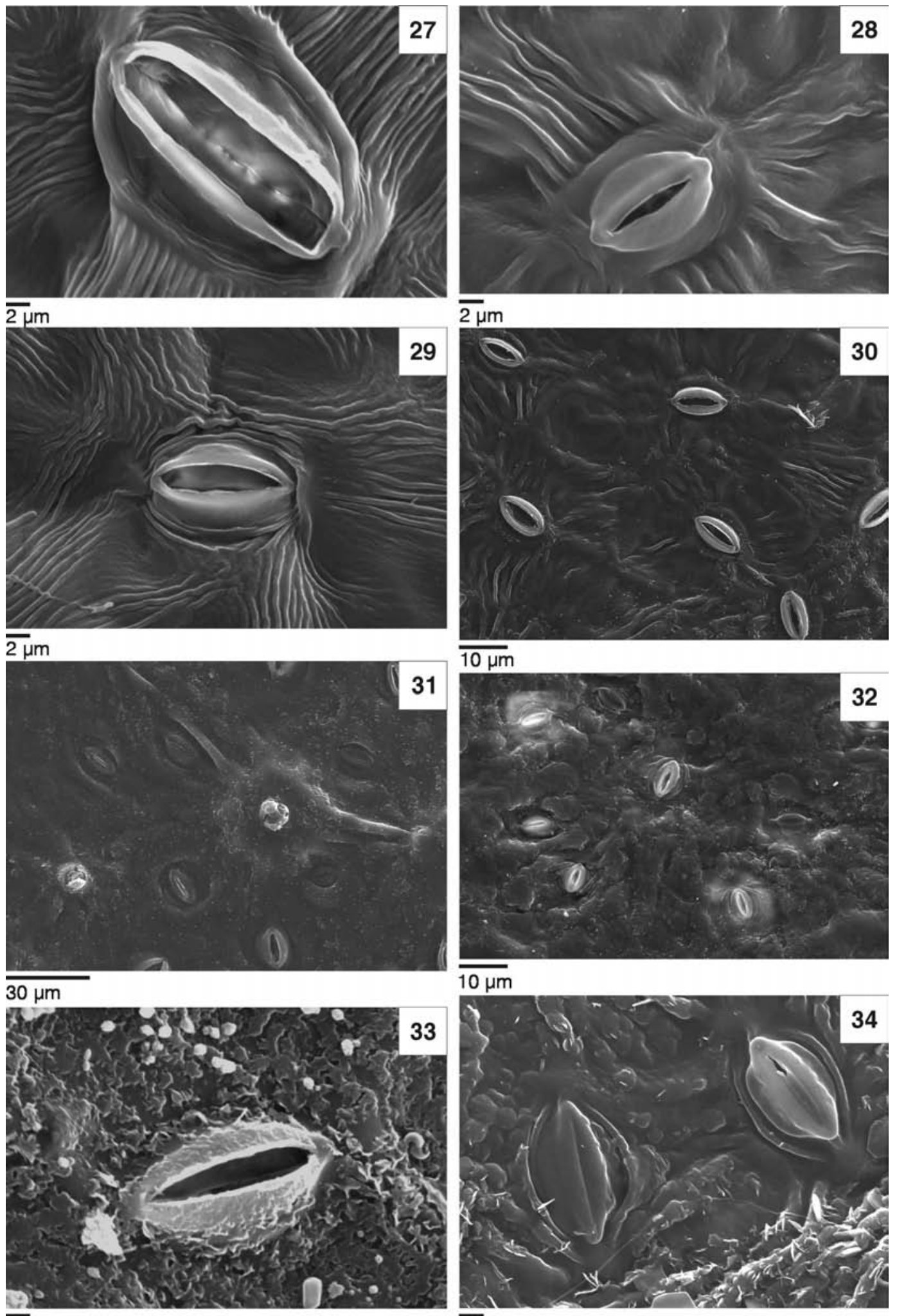

$\overline{2 \mu \mathrm{m}}$

$\overline{2 \mu \mathrm{m}}$

Figs 27-34. SEM. Abaxial epidermis of Ficus leaves with stomata, cuticle and wax: Fig. 27. F. carica; Fig. 28. F. pumila 'Minima'; Fig. 29. F. sycomorus; Fig. 30. F. macrophylla; Fig. 31. F. neriifolia; Fig. 32. F. natalensis subsp. leprieurii; Fig. 33. F. religiosa; Fig. 34. F. triangularis. 

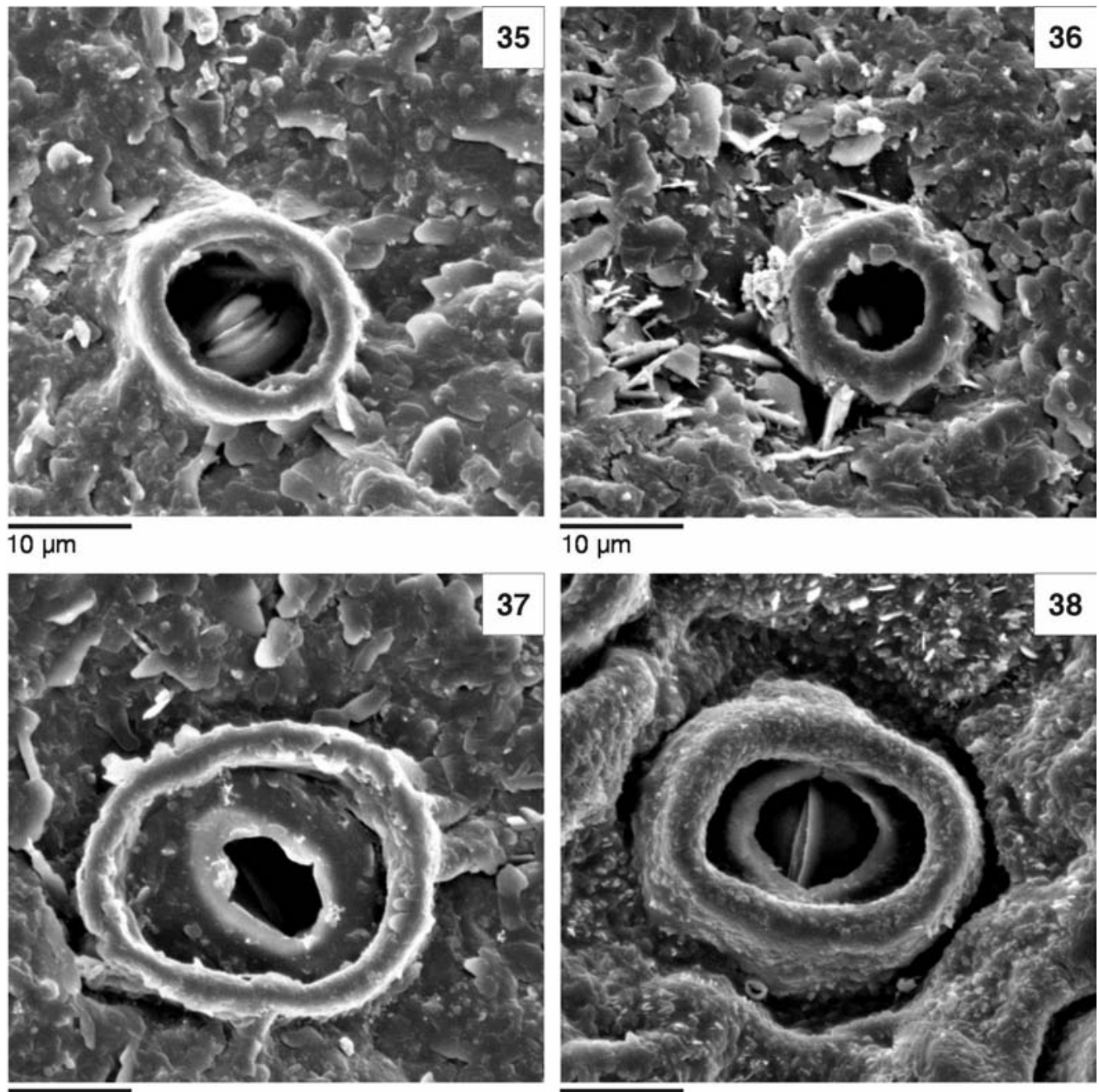

$10 \mu \mathrm{m}$

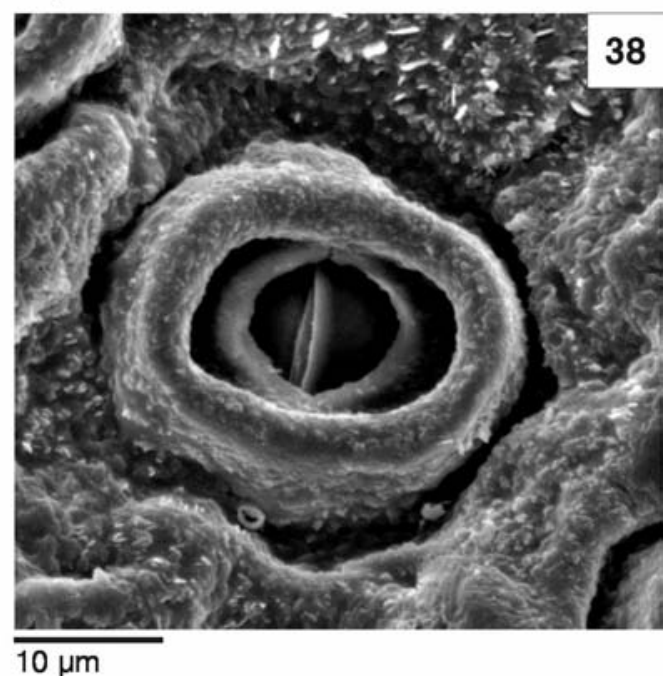

Figs 35-38. SEM. Abaxial epidermis of Ficus leaves with stomata, cuticle and wax: Fig. 35. F. benjamina; Fig. 36. F. benjamina 'Foliole'; Fig. 37. F benjamina 'Golden King'; Fig. 38. F. benjamina 'Variegata'.

diploid $(2 \mathrm{n}=26)$ except for the triploid $F$. elastica $(3 \mathrm{n}=$ 39).

In our study large stomata, with the mean of over 30 $\mu \mathrm{m}$ were found in 3 diploid species and a cultivar of $F$. benjamina 'Exotica'. The mean length of a triploid $F$. elastica and its cultivars ranged from 20.33 to $30.77 \mu \mathrm{m}$. However, the longest stomata were found in F. carica, which is a diploid.

It results from the calculated Pearson's correlation coefficients that stomatal length is not correlated with their density. The analysis of variance ANOVA (Table 4 and 5) was performed for a simple classification at $\alpha=0.01$ and $\alpha=0.05$. On the basis of $\mathrm{NIR}_{\mathrm{T}}$ (Ott 1984) it was found that in most taxa the mean length and density of stomata per 1 $\mathrm{mm}^{2}$ differ considerably. The performed Tukey's test ( $\alpha=$ $0.01, \alpha=0.05$ ) made it possible to establish 15 groups of homogeneous analyzed taxa for the analyzed quantitative traits.

Cluster analysis based on qualitative traits (Fig. 50) presents two clusters between which the Euclidean distance is
65. The first cluster is composed of two groups and includes 33 taxa from four subgenera. Ficus carica (subg. Ficus) takes an isolated position. The second cluster includes only two species from subgenera Sycomorus and Urostigma.

The size and arrangement of stomata to a large extent are determined genetically, but depend also on the conditions under which a leaf developed, thus reflecting the phenotypic plasticity of the plant (Hejnowicz 2002).

Cluster analysis of quantitative traits (Fig. 51) presents also two clusters and the Manhattan distance is 68 . The first cluster is composed of 19 taxa and is divided into two groups. One includes all the taxa from subgenera Ficus, Synoecia and three species from subg. Urostigma. The other cluster is divided into three groups. The first group includes one analyzed species from subgenus Pharmacosycea and seven from subgenus Urostigma from various sections: Galoglichia, Urostigma and Malvanthera. The two other groups include only taxa from subg. Urostigma. Six colourful cultivars of $F$. benjamina and $F$. elastica belong to the third group. 

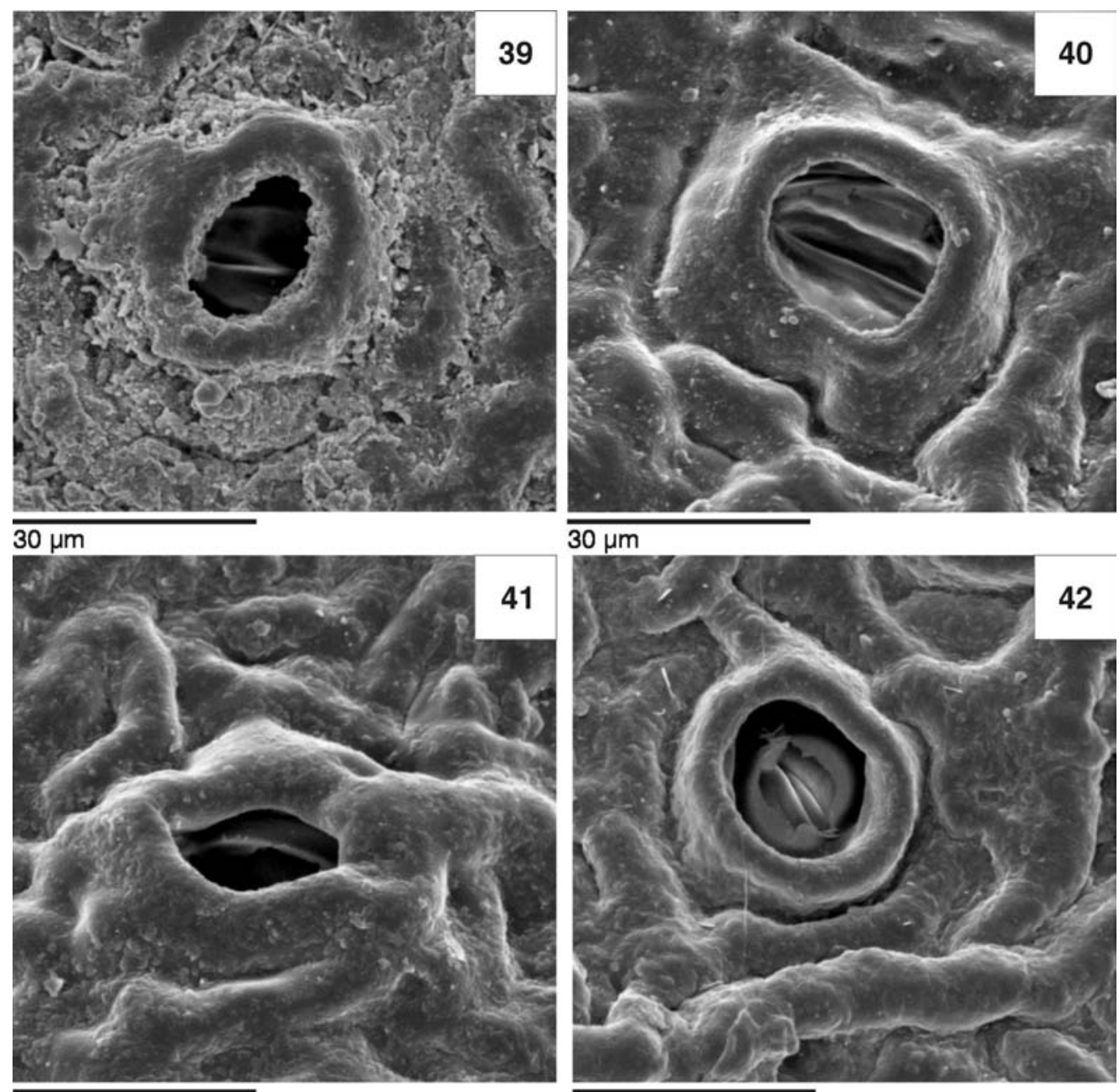

$30 \mu \mathrm{m}$

$30 \mu \mathrm{m}$

Figs 39-42. SEM. Abaxial epidermis of Ficus leaves with stomata, cuticle and wax: Fig. 39. F. elastica; Fig. 40. F. elastica 'Decora'; Fig. 41. F. elastica 'Schrijveriana'; Fig. 42. F. elastica 'Variegata'.

Summing up, on the basis of cluster analysis it may be stated that selected quantitative and qualitative traits appropriately distinguish species, subspecies and cultivars. Micromorphological traits, especially those of the abaxial epidermis show bigger variation and thus are more useful in the taxonomy of the genus.

At the same time, of $F$. triangularis has been treated as a synonym of $F$. leprieurii (Alexander 1989). However, in terms of the length and density of stomata is show considerable similarity to $F$. natalensis subsp. leprieurii, while in quantitative traits to F. religiosa from subg. Urostigma.

\section{CONCLUSIONS}

1. The shape of epidermal cells and their walls is a good diagnostic feature for the identification of species on the basis of leaf anatomy.

2. The nature of the trichomes (unicellular, nonglandular, peltate, uniseriate and capitate) in the genus seems to be more reliable than their presence or absence.
3. Laminar hydathodes in most taxa (34) are found on the abaxial leaf surface primarily on lateral veins.

4. The location of lithocysts and their types well distinguish taxa of lower rank and they do not depend on the number of epidermis layers.

5. In subg. Ficus lithocysts with a cystolith were found only on the abaxial leaf surface in the other subgenera and all sections in both adaxial and abaxial epidermis.

6. Epicuticular waxes and cuticle on the abaxial epidermis exhibit great micromorphological diversity.

7. Glandular spots (wax glands) were present in the leaves of Ficus taxa (all subgenera and sections) occurring on both surfaces: adaxial and abaxial, either singly on the midrib and at the base of lamina or in the angles between primary lateral veins and on the leaf margin.

8. Ficus leaves are hypostomatic, stomata are of the anemocytic type. Stomata are found on the whole leaf surface between veins and in clusters only in 4 species from subgenus Urostigma.

9. Stomata elliptic in outline are located more or less in the level of the epidermis in taxa of subg. Ficus, Synoecia, 

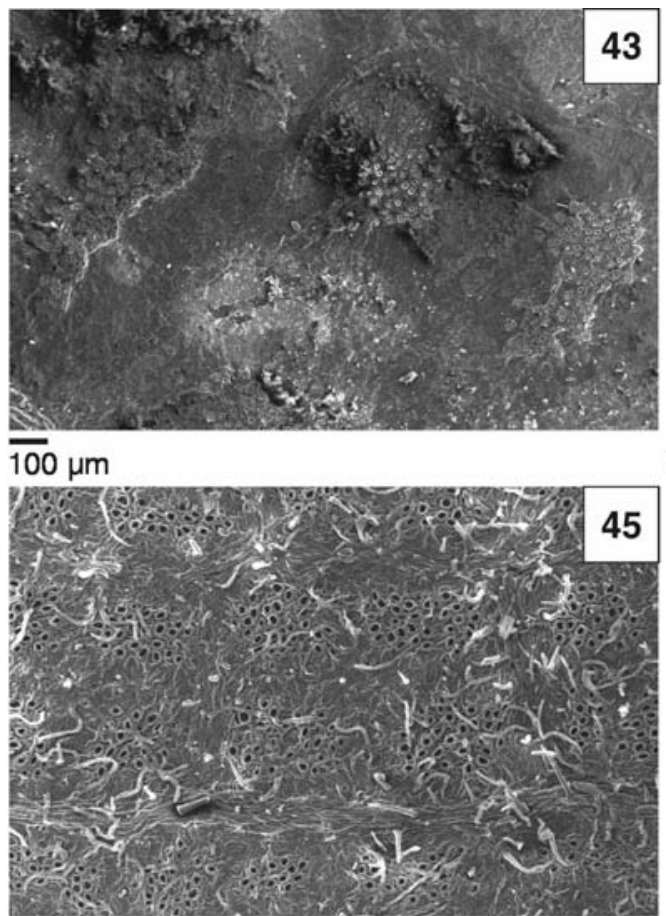

$\overline{100} \mu \mathrm{m}$

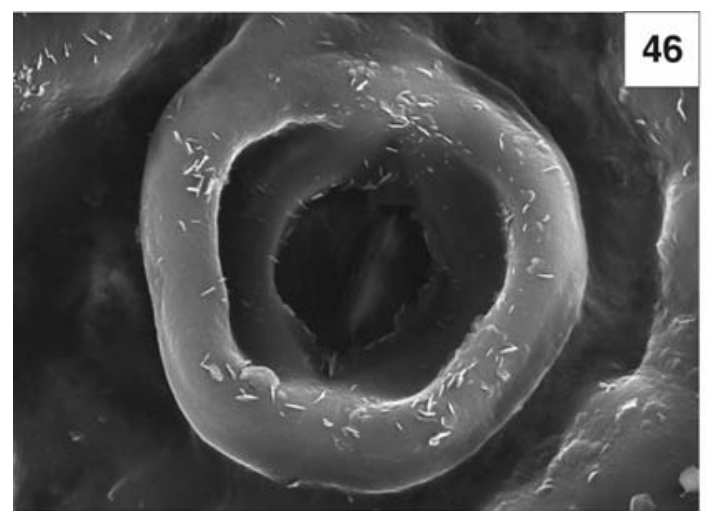

$\overline{2 \mu \mathrm{m}}$

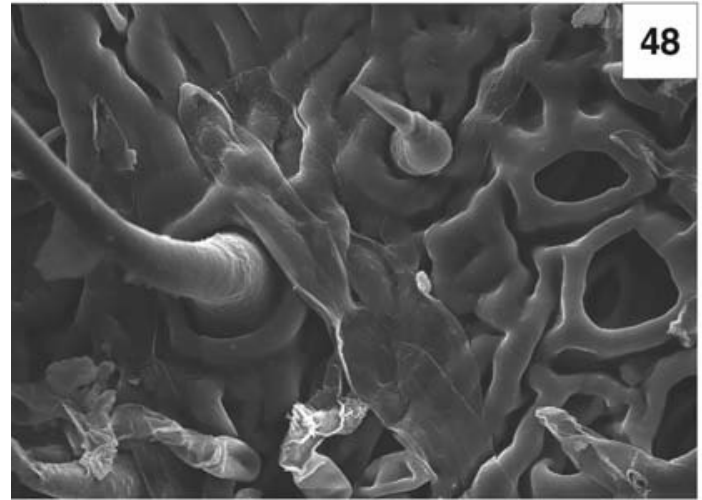

$\overline{\overline{10}} \mu \mathrm{m}$

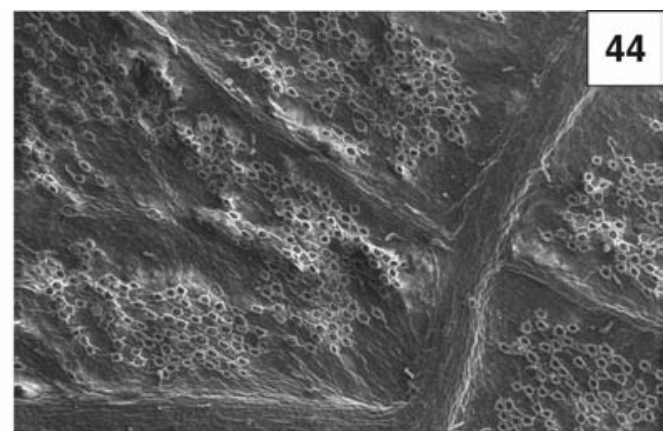

$\overline{200 \mu \mathrm{m}}$

Figs 43-45. SEM. Distribution of stomata of Ficus: Fig. 43. F cyathistipula subsp. cyathistipula, note the groups of stomata; Fig. 44. F. lyrata, note the groups of stomata; Fig. 45. F. rubiginosa, note the groups of stomata.

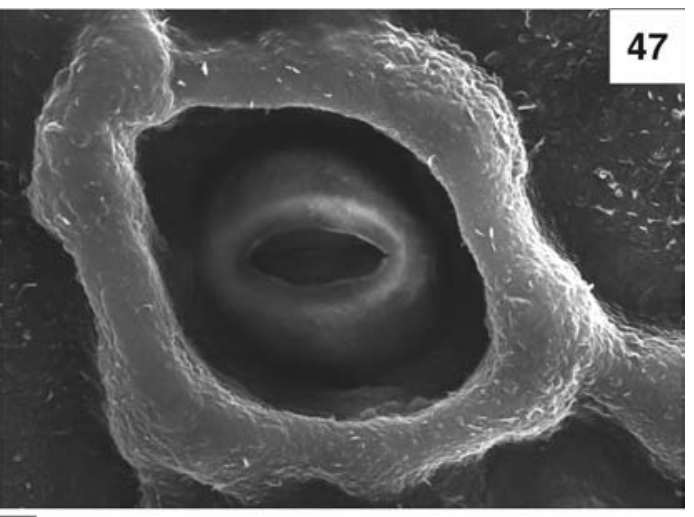

$\overline{2 \mu \mathrm{m}}$

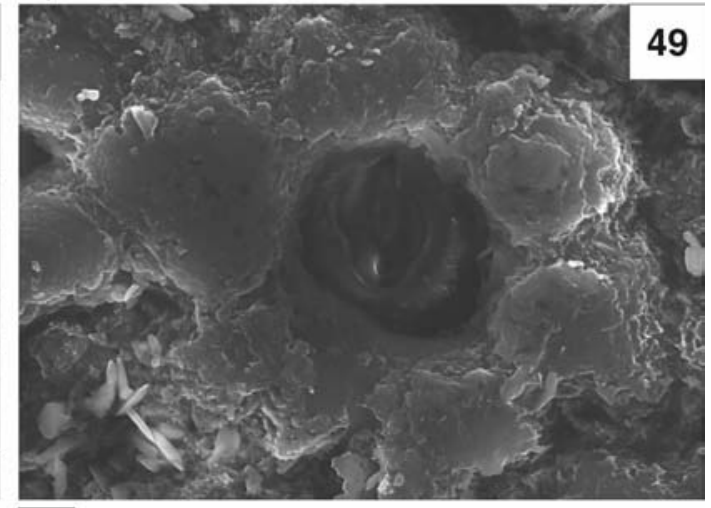

$\overline{3 \mu \mathrm{m}}$

Figs 46-49. SEM. Shape of the peristomal rim of Ficus: Fig. 46. F. microcarpa; Fig. 47. F. lyrata; Fig. 48. F. rubiginosa; Fig. 49. F. cyathistipula subsp. cyathistipula. 
TABLE 4. Analysis of variance of the length of stomata in Ficus.

\begin{tabular}{lcccc}
\hline Source of variation & Degrees of freedom & Sum of squares & Mean square & Test statistic \\
\hline Taxon & 35 & 30657.9 & 875.9 & 117.01 \\
Erorr & 864 & 6468.1 & 7.5 & \\
Total & 899 & 37126.0 & \\
\hline
\end{tabular}

$\mathrm{NIR}_{\mathrm{T}} 2.74$

$\mathrm{NIR}_{\mathrm{T}} 3.09$

TABLE 5. Analysis of variance of the stomatal density in Ficus.

\begin{tabular}{lcccc}
\hline Source of variation & Degrees of freedom & Sum of squares & Mean square & Test statistic \\
\hline Taxon & 35 & 616893 & 17626 & 555.97 \\
Erorr & 334 & 10589 & 32 & \\
Total & 369 & 627482 & \\
\hline
\end{tabular}

$\mathrm{NIR}_{\mathrm{T}} 8.92$

$\mathrm{NIR}_{\mathrm{T}} 10.06$

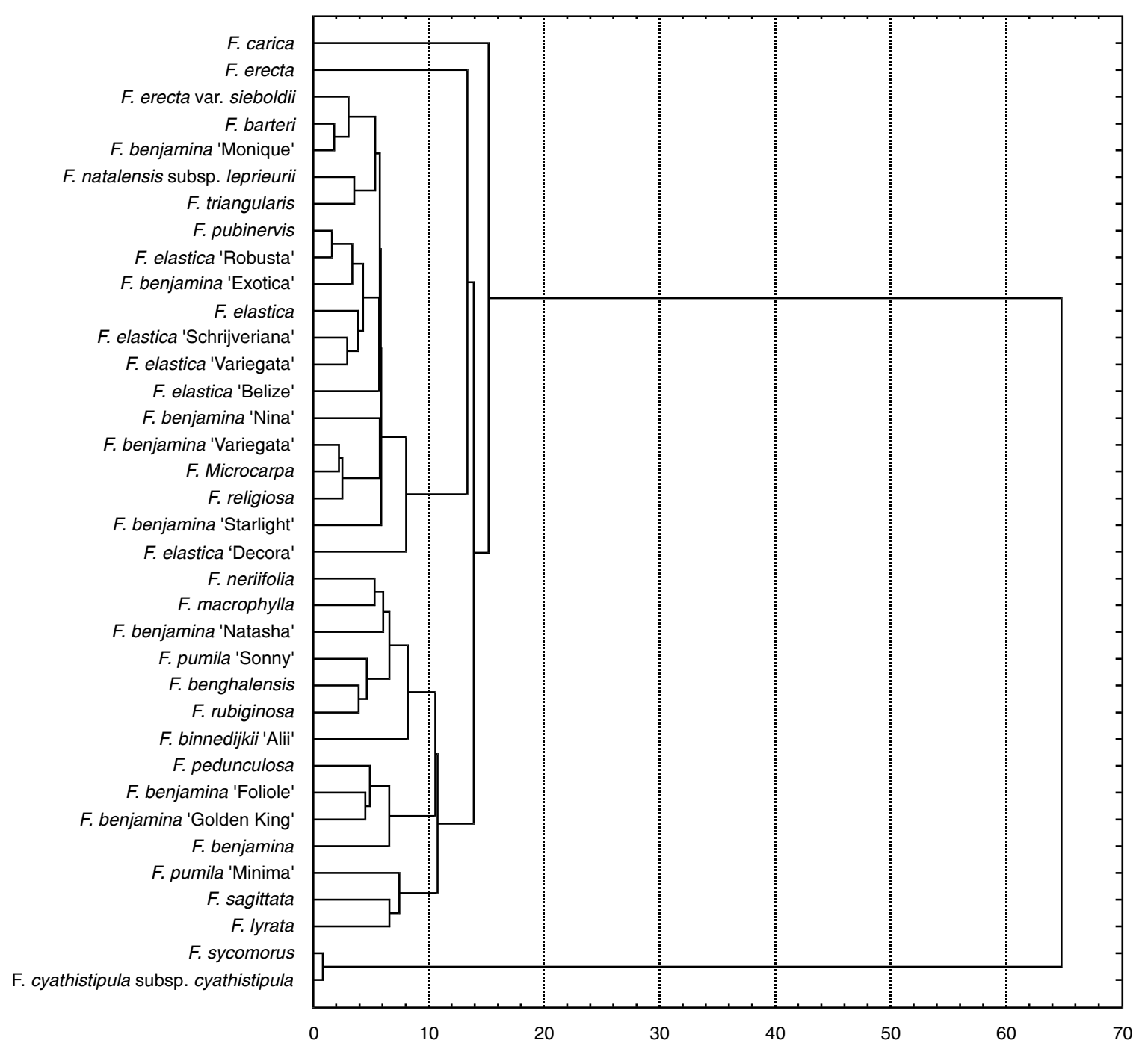

Fig. 50. Dendrogram constructed on the basis of qualitative epidermal leaf traits in Ficus taxa. 


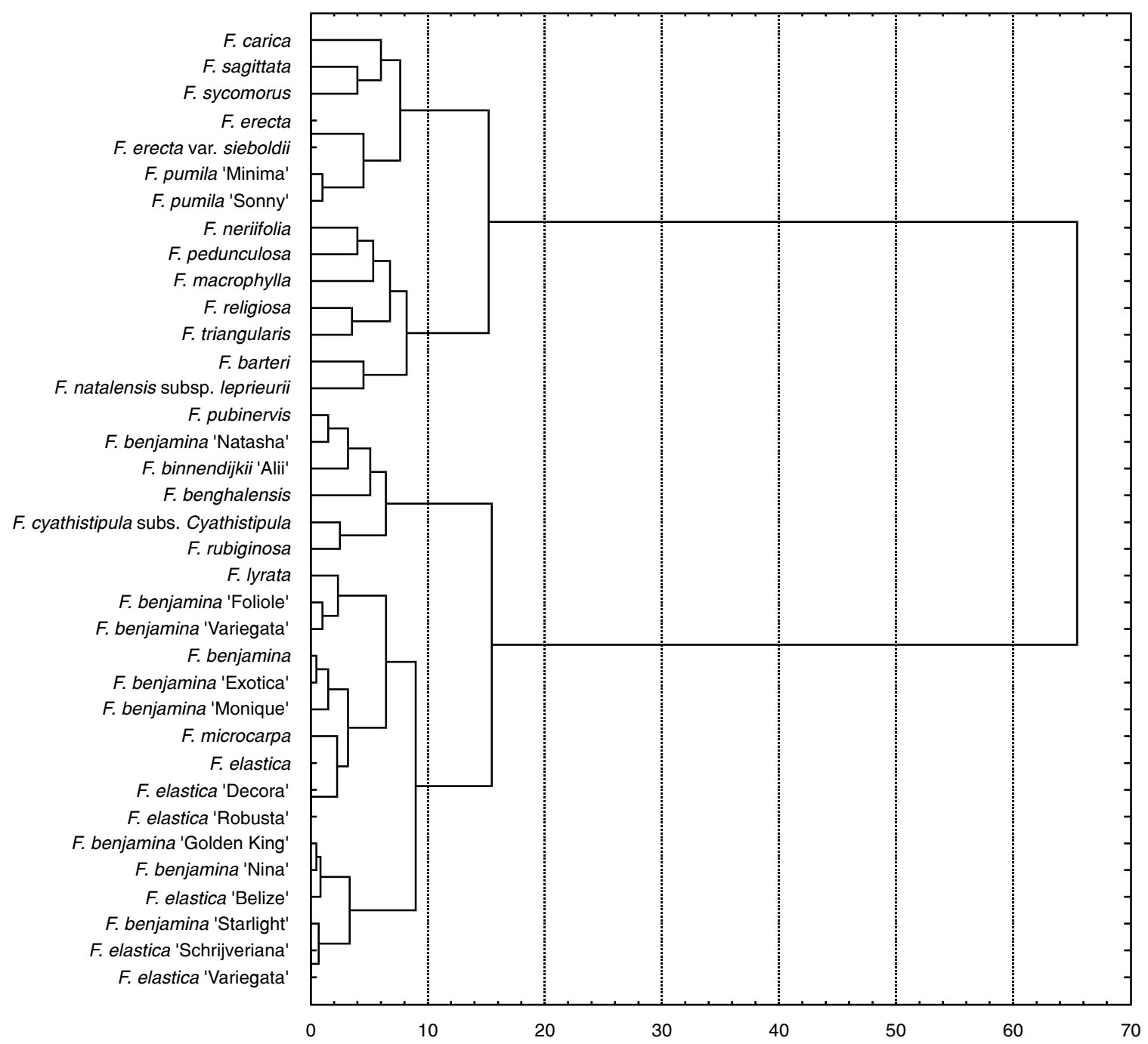

Fig. 51. Dendrogram constructed on the basis of quantitative epidermal leaf traits in Ficus taxa.

Sycomorus and three species from subg. Urostigma and $F$. triangularis; suborbiculate and deeply sunken in subg. Pharmacosycea and Urostigma.

10. The length and density of stomata per $1 \mathrm{~m}^{2}$ are noncorrelated characters and differences between species in most cases are statistically significant.

11. On the basis of cluster analysis it may be stated that qualitative and quantitative traits appropriately distinguish species, subspecies and cultivars, while they play a lesser role in intergeneric differentiation.

\section{LITERATURE CITED}

ABBOTT L.A., BISBY F.A., ROGERS D.J. 1985. Taxonomic Analysis in Biology. Computers, Models and Databases. New York.

ALEXANDER J.C.M. 1989. Ficus Linnaeus. In: The European Garden Flora. A manual for the identification of plants cultivated in Europe, both out-of-doors and under glass. Dicotyledons (Part I) Watters S. M., Alexander J.C.M., Brady A., Brickell C.D., Cullen J., Green P.S., Heywood V.H. (eds), Matte Canb. Univ. Pres. Cambridge, New York, Melbourne, Sydney: 90-101.
BERG C.C. 1989. Classification and distribution of Ficus. Experientia 45: 605-611.

BERG C.C. 1998. Phytogeography, systematics and diversification of African Moraceae compared with those of other tropical areas. In: Huxley C.R., Lock J.M., Cutler D.F. (eds), Chorology, taxonomy and ecology of the floras of Africa and Madagascar: 131-148. Kew.

BERG C.C. 1990. Reproduction and evolution in Ficus (Moraceae): traits connected with the adequate rearingot pollinators. Mem. N. Y. Bot. Gard. 55: 169-185.

BERG C.C. 2003a. Flora Malesiana precursor for the treatment of Moraceae 1: The main subdivision of Ficus: the subgenera. Blumea 48: 167-178.

BERG C.C. 2003b. Flora Malesiana precursor for the treatment of Moraceae 3: Ficus subgenus Ficus. Blumea 48: 529-550.

BERG C.C. 2003c. Flora Malesiana precursor for the treatment of Moraceae 4: Ficus subgenus Synoecia. Blumea 48: 551-571.

BERG C.C. 2004. Flora Malesiana precursor for the treatment of Moraceae 6: Ficus subgenus Sycomorus. Blumea 49: 155-200. BOLKHOVSKIKH Z., GRIF V., MATVEJEVA T., ZAKHARYEVA O. 1969 Chromosome numbers of Flowering Plants. AN. Fedorov A. (ed.) Acad. of Scien. of the USSR V.L. Komarov Bot. Inst. 
CHEN CH., CHEN Y. 2005. Study on laminar hydathodes of $F i$ cus formosana (Moraceae) I. Morphology and ultrastructure. Bot. Bull. Acad. Sin. 46: 205-215.

CLIFFORD H.T., STEPHENSON W. 1975. An introduction to numerical classification. Academic Press, New York.

CORNER E.J.H. 1960a. Taxonomic notes on Ficus Linn., Asia and Australasia. I-IV. Gard. Bull. Singapore 17: 368-485.

CORNER E.J.H. 1960b. Taxonomic notes on Ficus Linn. Asia and Australasia. Addendum. Gard. Bull., Singapore 18: 1-69.

CORNER E.J.H. 1961. Taxonomic notes on Ficus Linn. Asia and Australasia. Addendum. Gard. Bull., Singapore 18: 88-99.

CORNER E.J.H. 1962. Taxonomic notes on Ficus Linn. Asia and Australasia. Addendum II. Gard. Bull., Singapore 19: 385-401.

CORNER E.J.H. 1965. Check list of Ficus in Asia and Australasia with keys to identification. Gard. Bull. Singapore 21: 1-186.

DATWYLER S.L, WEIBLEN G. 2004. On the origin of the fig phylogenetic relationships of Moraceae from ndh F. sequences. Am. J. Bot. 91: (5): 767-777.

DIXON D.J. 2003. A taxonomic revision of the Australian Ficus species in section Malvantera (Ficus subg. Urostigma Moraceae). Telopea 10: 125-153.

DOBOSZ M. 2001. Wspomagana komputerowo statystyczna analiza wyników badań. Akademicka Oficyna Wydawnicza EXIT, Warszawa. (in Polish)

ESAU K. 1967. Plant anatomy. J. Wiley \& Sons, Inc., New York.

Ficus in Flora of China: http: //www.efloras.org/florataxon.aspx?flora

Ficus in Flora of North America: http: //www.efloras.org/florataxon.aspx?flora

HANS A.J. 1972. Cytomorphology or arborescent Moraceae. J. Arnold Arbor. 53: 216-225.

HEJNOWICZ Z. 2002. Anatomia i histogeneza roślin naczyniowych. Organy wegetatywne. Wydawnictwo Naukowe PWN, Warszawa. (in Polish)

HERRE E.A., MACHADO C.A., BERMINGHAM E., NASON J.D., WINDSOR D.M., MCCAFFERTY S.S., VAN HOUTEN W., BACHMANN K. 1996. Molecular phylogenies of figs and their pollinator wasps. J. Biogeogr. 23: 521-530.

KAROŃSKI M., CALIŃSKI T. 1973. Grouping in multivariate populations on the basis of Euclidean distances, Algor. Biometr. Statyst. 17: 117-129.

KLIMKO M. 1981. Zmienność populacji i stanowisko systematyczne Carex nigra (L.) Reich. w Polsce. PWN Warszawa-Poznań. Pozn. Tow. Przyj. Nauk. Wydz. Matemat.-Przyr. Prace Komisji Biologicznej T. LVIII: 1-72. (in Polish with English summary)

LERSTEN N.R., PETERSON W.H. 1974. Anatomy of hydathodes and pigment disks in leaves of Ficus diversifolia (Moraceae). Bot. J. Lin. Soc. 68: 109-113.

ŁOMNICKI A. 2000. Wprowadzenie do statystyki dla przyrodników. Wyd. Nauk, Warszawa. (in Polish)

MCNEILL J. 1975. A generic revision of Portulaceae tribe Montieae using techniques of numerical taxonomy. Can. J. Bot. 53: 789-809.

MELLO FILHO L.E., NEVES J. 1990. Anatomia foliar de Ficus benghalensis L. Bradea (5) 30: 324-333.
METCALFE C.R., CHALK L. 1950. Anatomy of the Dicotyledons. Oxford at the Clarendon Press, Vol. II: 1259-1271.

MIQUEL F.A. W. 1847. Prodromus monographiae Ficuum. London J. Bot. 6: 514-588.

MOLISCH H. 1916. Beiträge zur Mikrochemie der Pflanze. Nr 2. über orangefarbige Hydathoden bei Ficus javanica. Ber. Dt. Bot. Ges. 34: 66-69.

OTT L. 1984. An introduction to statistical methods and data analysis. PWS Publishers, Boston,

PHILPOTT J. 1953. A blade tissue study of leaves of forty-seven species of Ficus. Bot. Gaz. (115): 15-35.

RAMIREZ W.B. 1977. A new classification of Ficus. Ann. Missouri Bot. Gard. 64: 296-310.

RENNER O. 1907. Beiträge zur Anatomie und Systematik der Artocarpeen und Conocephaleen, insbesondere der Gattung Ficus. Bot. Jahrb. Syst. 39: 319-448.

RHS Colour chart 2001. The Royal Horticultural Society, London. ROHWER J.G. 1993. Moraceae. The Families and Genera of Vascular Plants. II Flowering Plants - Dicotyledons Magnoliid, Hamamelid and Caryophyllid Families. Kubitzki K., Rohwer J.G. and Bittrich V. (eds). Springer-Verlag, 438-453.

SHAH A.M. KACHROO P. 1975. Comparative anatomy in Urticales. I. The trichomes in Moraceae. J. Indian Soc. 54: 138-153.

SNEATH P.H.A., SOKAL R.R. 1973. Numerical Taxonomy. W.H. Freeman, San Francisco.

SONIBARE M.A., JAYEDA A.A., EGUNYOMII A. 2004. A morphometric analysis of the genus Ficus Linn. (moraceae). Afr. J. Biotechnol. 3 (4): 229-235.

SONIBARE M.A., JAYEOLA A.A., EGUNYOMI A., MURATA J. 2005. A survey of epidermal morphology in Ficus Linn. (Moraceae) of Nigeria. Bot. Bull. Acad. Sin. 46: 231-238.

SOKAL R.R., ROHLF T.J. 1997. Biometry: the principles and practice of statistics in biological research. Freeman W. H. \& Comp., San Francisco.

STACE C.A. 1993. Taksonomia roślin i biosystematyka. Wyd. Nauk. PWN. Warszawa. (in Polish)

STATSOFT INC. 2002. Statistica for Windows [User's manual], Tulsa.

STEBBINS G.L. 1958. Zmienność i ewolucja roślin. PWN, Warszawa. (in Polish)

VAN GREUNING J.V., ROBBERTSE P.J., GROBBELAAR N. 1984. The taxonomic value of leaf anatomy in the genus $\mathrm{Fi}$ cus. S. Afr. J. Bot. 3 (5) 297-305.

WEIBLEN G.D. 2000. Phylogenetic relationships of functionally dioecious Ficus (Moraceae) based on ribosomal DNA sequences and morphology. Am. J. Bot. 87: 1342-1357.

WIEBES J.T. 1994. The Indo-Australian Agaoninae (pollinators of figs). Verh. Kon. Ned. Akad. Wet., afd. Natk., 2 de reeks, 92: 1-208.

WIEBES J.T. 1995. The New World Agaoninae (pollinators of figs). Verh. Kon. Ned. Akad. Wet., afd. Natk., 2 de reeks, 94: $1-60$.

WINKELMANN T., GRUNVALDT J., 1995. Analisis of protoplast - derived plants of Saintpaulia ionantha H. Wendl. Plant Breeding 114: 346-350. 